\section{Inequality in Latin America: the role of the nature of trade and partners}

\author{
Teresa María García Muñoz, Juliette Milgram Baleix, \\ and Omar Odeh Odeh
}

\begin{abstract}
This paper investigates the relationship between trade openness and income inequality in 11 Latin American countries over the period 1989-2015. The authors use a panel dynamic approach to take into account the high persistence of income inequality. The analysis classifies trade flows, exports and imports according to trading partner's income level. Then, the authors split trade flows according to different stages of production. The results show that overall trade flows do not statistically affect income inequality in Latin America. However, trade has divergent effects depending on the trade partners: trade with similar- and lower-income countries exacerbates inequality, while trade with higherincome countries reduces income dispersion. The results also emphasise the role of the export channel (in particular in primary commodities) in explaining income inequality in Latin American countries and imports of consumption goods seem to matter more than imports of intermediate and capital goods.
\end{abstract}

(Published in Special Issue Recent developments in international economics)

JEL F14 O54 E25

Keywords Trade openness; trade direction; income inequality; Latin America

\section{Authors}

Teresa María García Muñoz, Departamento de Métodos Cuantitativos, University of Granada, Granada, Spain

Juliette Milgram Baleix, Departamento de Teoría e Historia Económica, University of Granada, Granada, Spain

Omar Odeh Odeh, « Departamento de Teoría e Historia Económica; University of Granada, Granada, Spain, omodjod@correo.ugr.es

Citation Teresa María García Muñoz, Juliette Milgram Baleix, and Omar Odeh Odeh (2020). Inequality in Latin America: the role of the nature of trade and partners. Economics: The Open-Access, Open-Assessment E-Journal, 14 (2020-25): 1-35. http://dx.doi.org/10.5018/economics-ejournal.ja.2020-25

Received October 29, 2019 Published as Economics Discussion Paper November 12, 2019 Revised February 28, 2020 Accepted June 29, 2020 Published July 21, 2020

(c) Author(s) 2020. Licensed under the Creative Commons License - Attribution 4.0 International (CC BY 4.0) 


\section{Introduction}

The question of how trade openness affects income inequality is still a matter of controversy. Theoretical predictions from the standard trade theory (Stolper and Samuelson, 1941) emphasise that trade openness would be beneficial to unskilled-labour in developing countries. However, they are not fully backward by empirical evidence (Goldberg and Pavcnik, 2007; Pavcnik, 2017). Accordingly, the literature insights into other mechanisms to resolve the contradictions between the theoretical predictions and the empirical findings, such as skill biased technological change (SBTC) induced either by technology transfer from North to South (Acemoglu, 2003), or by the production shift of unskilled-labour activities to the South (Feenstra and Hanson, 1996), or by Southern technological catch-up via the growth in the export of skill-intensive goods (Zhu and Trefler, 2005).

There exists an ongoing debate about whether income inequality is affected by trade flows in general or rather by specific aspects of openness (IMF, 2017). For instance, Jaumotte et al. (2013) find a more robust impact of technological progress than globalization on income inequality in a sample of 51 developed and developing countries. In Latin America, the region with the highest level of inequalities around the world, this debate seems even more relevant. The role played by trade partly depends on the extent to which trade reforms have affected the economy's productivity-enhancing structural change in the region. Wood (1997) argues that trade openness has shifted the production toward more skill-intensive goods in Latin America due to the integration of low-income exporters into the global economy, i.e. China and India. This argument is in line with the 'defensive innovation' term introduced by (Wood, 1995a), which states that the increased foreign competition provides incentives for firms to invest in new technologies. However, Mcmillan et al. (2014) argue that an "economy's overall productivity depends not only on what is happening within industries, but also on the reallocation of resources across sectors". They show that opening up to global economy impedes the movement toward more productive industries and strengthens traditional patterns of production in natural resource-based commodities countries. Thus, in this paper, we attempt to identify the possible channels through which trade openness would have affected income inequality in Latin America.

The empirical literature has reached inconclusive findings on the relationship between trade and inequality in Latin America. Some authors confirm a positive association (Attanasio et al., 2004 for Colombia; Hanson and Harrison, 1999 for Mexico), while others report a negative association (Ferreira et al., 2007 for Brazil), or others point out no effect of trade on inequality (Pavcnik et al., 2004 for Brazil). A common shortcoming in these studies is the focus on trade reforms, embodied in tariff changes, to explain inequality. These studies, hence, adopted de jure indicators of openness and ignored de facto flows. Moreover, studies on Latin America have neglected the role played by the aforementioned mechanisms (Acemoglu, 2003; Feenstra and Hanson, 1996; Zhu and Trefler, 2005) in the relationship between trade openness and income inequality (see Székely and Mendoza, 2015; 2017 for Latin America). This paper, therefore, aims to fill these gaps. More specifically, we go deep into the relationship between trade openness and income inequality by adopting a more disaggregated analysis of trade, exports and imports. Building on the idea that trade in manufactured products and, in particular, imports of intermediate and capital products from developed countries may induce technology transfers, 
we disaggregate trade flows by type of trading partners and type of products to isolate their potential impacts on income inequality. The analysis covers a sample of 11 Latin American countries over the 1989-2015 period. We also account for the fact that inequality is a heavily persistent phenomenon, which is not accurately tackled in the literature except by Meschi and Vivarelli (2009). For this purpose, we use a dynamic panel approach that ensures robust and efficient estimators of the effect of trade openness on income inequality. As the number of period is large, we use panel data estimators with fixed effect.

The results suggest that overall trade do not have a significant effect on the dispersion of income in Latin American countries. However, the nature of trading partners matters more for inequalities. When we disaggregate trade according to partners' relative income level, we find a decreasing-inequality effect of trade with higher-income countries, while if the trading partner is similar-or lower-income countries, inequality tends to worsen. Once trade flows are disaggregated by stage of production, it appears that trade in agriculture goods, oil and mining goods and consumption goods play an important role in explaining the relationship between trade openness and income inequality, while trade in equipment and intermediate goods do not play any role for the countries of our sample. We also observe that income inequality is more affected through the export channel than the import channel, mainly through the exports of primary commodities, which lessen inequality.

The study proceeds as follows: Section 2 describes the literature, which is followed by the data and empirical strategy in Section 3. Section 4 presents the results, after which the discussion of the results and concluding remarks are given in Section 5.

\section{Literature Review}

According to standard trade theory (Stolper and Samuelson, 1941), trade openness would reduce the wage gap among skilled and unskilled workers in developing countries, since trade opening would lead to a rise in the relative price of unskilled-labour intensive goods in a low-skilled developing country and to an increase in the demand of unskilled-labours. This effect could be delayed according to Atolia (2007), who suggests that inequality could decline only in the longterm due to asymmetries in the speed of contraction in the import sector relative to the expansion in the export sector and the capital-skill complementary in production. This argument is empirically validated by cross-studies on Latin America, which indicate an initial disequalizing effect of trade openness on income inequality, but this effect considerably appears to fade away over time (Behrman et al., 2007; Székely and Mendoza, 2015). On the other hand, Davis (1996) puts forwards the hypothesis that the effect of trade openness on inequality depends on the reference sets, factor abundance of a country is compared to. He shows that a developing country, which is unskilled-labour abundant by global standards, might experience an increase in wage inequality if it is abundant in skilled-labour within its own reference set. Hence, the distributional consequences of trade may not reconcile with the Stolper-Samuelson's prediction for developing countries. Wood (1997) echoes this argument and attributes the rising income inequality in Latin America in the 80s and 90s to the emergence of large low-income 
exporters, such as China and India, which shifted their comparative advantage toward intermediate skill-intensive goods.

The literature on the topic has underlined several mechanisms through which trade openness may affect inequality in developing countries in an intent to reconcile theoretical predictions and empirical findings. The first mechanism introduced by Feenstra and Hanson (1996) links the rising wage inequality in the South to the reallocation of the production of intermediate goods from the North to the South. By increasing the production of these goods, which are unskilled labour-intensive relative to Northern standards and skill-labour intensive relative to Southern standards, the relative wages of skilled-labour increases and consequently wage inequalities worsens in both regions. The role played by imported intermediate inputs is backed up by empirical evidence, which shows that intermediate goods can indeed foster quality upgrading and shift the production towards more skill-intensive goods, which would increase the demand of skilled workers (Crinò, 2012; Fernandes and Paunov, 2013; Kasahara et al., 2016). Based on the perspective of Feenstra and Hanson (1996), Zhu and Trefler (2005) argue that trade shifts can be also induced through Southern technological catch-up, which moves the production of unskilled-intensive goods from the North to the South. These products would correspond to the most skill-intensive according to Southern standards and this, in turn, would foster wage inequality in both regions.

Another mechanism suggests that trade openness can indirectly worsen wage inequality through technology transfer from the North to the South, which, in turn, fosters SBTC in developing countries because these technologies are more skill-biased than pre-trade local technologies (Acemoglu, 2003). Robbins (2003) introduces the 'skill-enhancing trade hypothesis' to explain the nexus between trade openness and wage inequality in developing countries, which predicts that trade openness accelerates the imports of capital goods and of new technologies in the South. This would, in turn, increase the demand for more skilled labours in the South and widen the unskilled-skilled wage gap. More recently, Wang and Yin (2016) find that technology transfer from the developed countries propels wage inequality in the host country. The empirical studies by Conte and Vivarelli (2011), and Sánchez-Páramo and Schady (2003) offer evidence supporting this argument for low- and middle-income countries, and Latin America, respectively, whereby the imported technologies from developed countries increase the demand for skilled-labour in these countries. In contrast, Gourdon (2011) finds that South-South trade leads to technical change that is more biased toward more skill-intensive sectors and this, in turn, would fuel wage inequality in lower-middle and low-income countries more than North-South trade does. In contrast, Meschi and Vivarelli (2009) conclude that only trade with developed countries leads to technological change in developing countries, hence boosting income inequality.

Other studies have underlined that technological change in developing countries is not only driven by imports but also by exports. This stems from the fact that access to export markets generates an increase in revenues for exporting-firms, making it profitable for them to invest in technology (Bustos, 2011a) and thereby increasing the demand for skilled-labour (Bustos, 2011b). Matsuyama (2007) provides another explanation of why the act of exporting per se favours skilled labours. He argues that exporting requires activities that are biased in favour of skilled-labours, such as language knowledge and marketing. However, Brambilla et al. (2012) lend partial support for this argument in Argentina. Alternatively, other authors have suggested 
that exporting per se does not necessarily stimulate the demand of skilled labours and the use of new technologies. Rather, the destination of exports would matter more. Verhoogen (2008) emphasises a mechanism where exporting to high-income countries allows for quality upgrading in Mexico. According to this author, the production of goods to serve high-income markets requires more skilled labours than producing for home or low- and middle-income countries because individuals in high-income countries have a higher income level and valuate high-quality products. Brambilla and Porto (2016) and Brambilla et al. (2012) lend support for the 'quality upgrading' mechanism in a panel of developing countries and Argentina, respectively. A different argument is provided by Brambilla et al. (2019), which points out that exporters do not equally expand their demand for all type of skilled labours because exporting requires tasks that demand a specific type of skills. They empirically find that exporting-firms in Chile have shifted the labour demand in favour of engineers over skilled administrative workers and managers.

In view of the foregoing, the relationship between trade openness and income inequality in Latin America may indeed be influenced in different ways by the nature of its exports and of its import structures. As intermediate countries (in terms of development level), the relative abundance in production factors may vary depending on the trading partners considered and trade flows could also have different impacts on inequality depending on the destination and origin of these flows.

On the exporting-side, Rodríguez-Pose and Gill (2006) suggest that trade composition may influence regional inequality. According to these authors, when manufacturing exports gain in importance over primary exports, regional inequality tends to ascend. However, in a region where the relative size of primary sector exports is still considerable in the exports basket, the distributional consequences of exports on income inequality may follow a different trajectory, which depends on the relative skill composition used in the production of primary goods. Székely and Mendoza (2017) argue that, in this vein, the world demand for primary goods may either improve or worsen the distribution of income, depending on whether their production is relatively intensive in skill and capital (e.g. oil extraction and mining) or relatively intensive in unskilled-labour (e.g. foodstuffs). On the importing-side, the literature widely confirms that imports from North deteriorate both wage and income inequality in the South due to technological differences between the two regions (Acemoglu, 2003; Meschi and Vivarelli, 2009). Imports from middle-income countries may also cause inequality to grow. As noted by Gourdon (2011), trade within developing countries leads to technological skill-biased toward more skill-intensive sectors and hence widening inequality. Imports from low-income countries may include standard technology and, in turn, would not induce any effect on inequality (Gourdon, 2011; Meschi and Vivarelli, 2009).

As shown before, the empirical studies have alternatively focused on the effects of trade on wage inequalities or on income inequalities, while most theoretical trade models focus on the effect of trade on wage inequalities. This requires a more detailed attention. In the mid-90s, there was a critical need to identify alternative mechanisms of how trade openness can affect inequalities in developing countries since the facts did not fit the prediction of the HeckscherOhlin trade model, assuming that income inequality evolves in the same manner as skill premia. As explained before, a plausible conjuncture for that is the role played by technology transfer and innovation, production shift and investments. Harrison et al. (2010) argue that these new 
theoretical developments explain, "How trade could contribute to rising within-industry inequality as well as rising inequality in countries at all income levels".

We argue that it is more interesting to focus on income inequality, which has a clearer socio-economic meaning than on wage inequality, despite some drawbacks discussed in the Methodology section. There are several reasons for that. Firstly, wage inequality is sectorspecific and would not account for indirect effect of trade on wages in other sectors. Trade of goods from a specific sector is expected to have a direct effect on wages of the exporting sector, as well as on wages of the import-competing sector of these goods. Secondly, the literature also suggests trade indirectly drive effects on the other sectors they provide inputs to, or they are clients of. Then, trade affects wage gaps within sector, but also between sectors. These effects are not captured by wage inequalities at the sector level. Thirdly, the overall effect on households' income also depends on changes in labour supply (Gasparini et al. 2011; Gasparini and Lustig 2011), fiscal policies, number of wage earners in the household, and additional income sources (Wood, 1995 b). In this regard, tax revenue is low in Latin America and mainly comes from indirect taxation, thus exacerbating income inequalities (World Bank, 2014). Lopez-Calva et al. (2015) provide some clues on the relationship between labor and income inequality for Latin America: "The decline in inequality in the region has been mostly driven by a fall in labor income inequality - explained by a reduction in the returns to education-and by more progressive and better-targeted government transfers (Lopez-Calva and Lustig 2010; Lustig et al. 2013; Gasparini et al. 2011). The reduction in skill premiums, in turn, tends to reflect a combination of enhanced access to education, rising the relative supply of skilled workers". In sum, focusing on wage inequalities leads to a more straightforward verification of the direct effects of trade flows, but do not account for all the indirect effects induced by trade, which is in our opinion, are more meaningful. Besides, studies focusing on income inequality in a panel of countries are scarce (see for instance Székely and Mendoza, 2015; 2017), so we consider that our study could fill this gap.

Based on the previous literature, changes in the distribution of wages and income in developing countries can be driven by standard explanations as well as by new trade theories. Traditional explanations suggest that trade openness would decrease inequality in country unskilled-labour abundant. However, Davis (1996) nuances this conclusion by underlining that factors abundance of one country varies according to the reference set. Thus, inequality could grow in a Southern country unskilled-labour abundant by global standards but skilled-labour abundant relative to other Southern countries. On the other hand, more recent theories suggest that trade openness allows for technology upgrading in developing countries either through the import channel (capital goods and outsourcing of "intermediate goods") or through the export channel (quality-upgrading mechanism), which is conditional upon partners' income levels. Thus, the effect of trade on income inequality may vary depending on the nature of the product traded and the nature of the trading partners. 


\section{$3 \quad$ Methodology}

To assess the nexus between trade openness and income inequality in Latin America, we face the problem of the accurate measure to account for inequality. As pointed by Thomas Piketty, Emmanuel Saez, or Gabriel Zucman, Gini indicators that measure income inequality based on household surveys suffer from several drawbacks. In particular, Alstadsæter et al. (2018) consider how much wealth is held in tax havens and who owns the wealth in tax havens to construct top income and wealth shares for different countries. Moreover, rich people often do not report their correct income or do not respond at all, and income inequality is measured with error (see Anand and Segal 2015: 945-948). Following the seminal works by Piketty (2001) and Piketty and Saez (2003), many scholars used official tax records and computed pre-tax top income shares for a number of countries. The collection is compiled in the WID - World Wealth and Income Database (Atkinson et al. 2011). Unfortunately, the main limitation of alternative inequality measures, such as the ones provided by the World Inequality Database (WID) is the lack of data, especially for developing countries (see Alvaredo et al., 2017). For the purpose of our study, WID covers only the following Latin American countries: Argentina, Brazil, Chile, Colombia and Uruguay at different time spans and for different indicators, such as average income, average wealth, income shares and wealth shares. This heterogeneity does not allow us to perform panel estimations.

The Standardized World Income Inequality (SWIID), which standardizes the United Nations University database (UNU-WIDER 2008) minimise reliance on problematic assumptions by using as much information as possible from proximate years within the same country. According to Solt (2016), the creator of SWIID, the best source in terms of comparison is the Luxembourg Income Study but it is only available for developed countries. The World Bank and EHII (Estimated Household Income Inequality) provide also GINI measures for Latin American countries but the time coverage is lower than SWIID. Comparing Gini index from SWIID and Gini index from the World Bank, we observe also a high correlation of 0.84 when using the whole information available for the period 1989-2015. Graph 14 illustrates this relationship for 2015. For all these reasons, we chose to rely on Gini indicators from SWIID since the data comparability is considered as much as maximum and maintain the widest possible coverage across countries and over long periods.

Moreover, we chose to focus on income inequality instead of wage inequality. First, it is important to note that wage inequality data available for Latin America come from national household surveys, which are not uniform across, and even within countries, in terms of geographical coverage and questionnaires over time. Thus, studying wage inequalities in a panel of countries, leads to comparability problems and loss of accuracy. That is why most previous studies on wage inequality in Latin America have only dealt with country case studies (e.g. Attanasio et al, 2004 for Colombia; Galiani and Porto, 2010 for Argentina; Gonzaga et al., 2006 for Brazil). Apart from these methodological problem, we consider that income inequality better accounts for all the effects driven by trade that wage inequalities as discussed in the previous section. 
Graph 1: Gini SWIID and Gini index from the World Bank in 2015

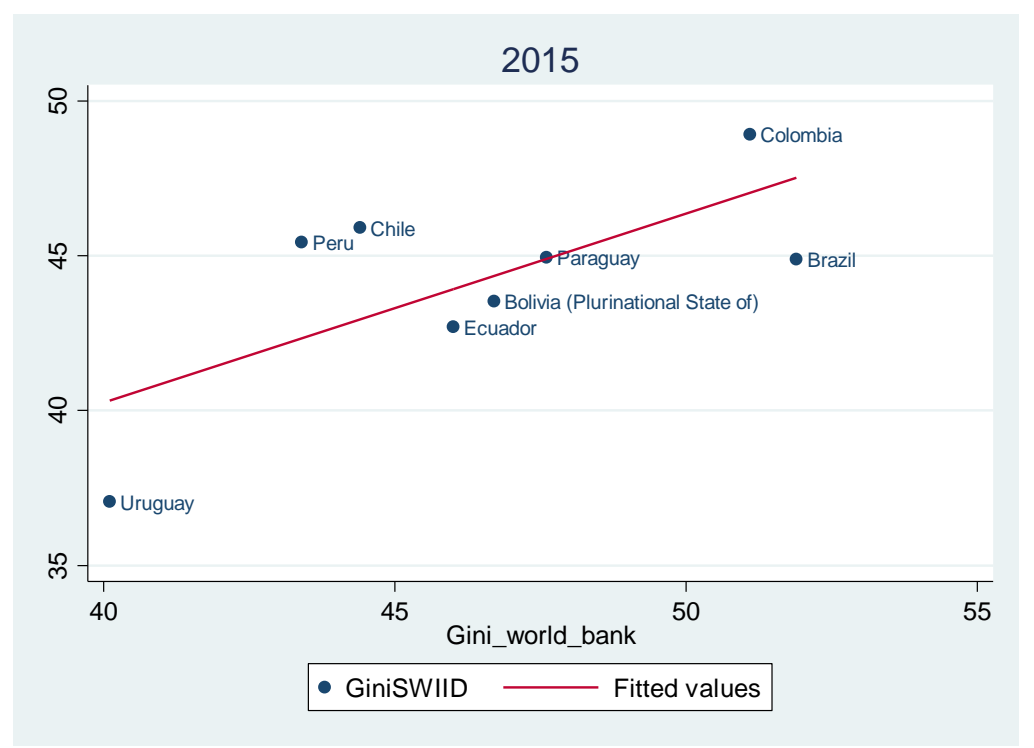

Source: Standardized World Income Inequality (SWIID) and World Bank

Another decision concerns how to measure trade integration. Gross trade may not accurately reflects the net value added incorporated in trade flows due to the integration in Global Value Chains. However, Latin American countries (except Mexico) have forward linkages with the rest of the world since they are natural resources abundant countries. By the same token, the degree of openness per se does not fully reflect countries' trade connections with the rest of the world. Regarding the measurement of connectedness, Arribas et al. (2009) propose indicators that take into account the architecture of trade connections, the weight of trading flows compared with partners' sizes. They highlight that South America appears as not highly integrated in global trade by highly connected. Based on a network approach, Reyes et al. (2010) propose relevant indicators (e.g. first-and higher-order connectivity and clustering measures) to examine the evaluation of international economic integration in East Asia and Latin America. They find that both regions experienced an increase in their degree of openness, while there is a considerable difference in their integration levels into the world economy. In particular, according to these authors, Latin America has a lower integration degree in the world trade network, standing in contrast with the case of East Asia, which has a higher integration degree in the world trade network. In fact, Latin America's economic integration is impeded by its comparative advantage (natural resources-based commodities), which is one of the main limitations of its participation in the global value chains (except Mexico). To take into account these considerations, we use measures of trade openness expressed in terms of GDP rather than trade openness in absolute terms and we also disentangle trade flows in order to take into account the geography of trade.

Regarding the estimation method, we consider a dynamic panel approach, which enables us to account for the high persistence of income inequalities. As a matter of fact, there are a range 
of factors that may affect long-term trends of the distribution of income, such as reductions in fertility, education, use of human capital (see Székely and Mendoza, 2017 for instance), type of growth and institutions (see Hartmann et al. 2017 for a survey), fiscal and labour policies (Papanek and Kyn, 1986), and structure of ownership and structure of production. Thus, it is beyond the scope of our study to gauge the long-term determinants of income inequality. Instead, we focus on middle- and short-term impacts of trade on within-country income inequality. Then, the chosen specification controls for the long-term determinants of inequality, even if we are not able to precise which factors there are.

Generalized least squares, Within Groups (WG) and Ordinary Least Squares (OLS) estimators are biased when lagged dependent variable is included as explanatory variable. A suitable dynamic panel data technique to overcome this problem is the difference Generalized Method of Moments (GMM) estimation (Arellano and Bond, 1991). However, when the number of period is large, as it is our case, dynamic bias becomes insignificant (Roodman, 2009) and panel data estimators with fixed effect estimator is another good option to tackle the estimation of dynamic models. This method also allows to control for the unobserved heterogeneities within countries and to take into account the quasi-fixed country structural factors that affect the level of income inequality but do not change over time, such as institutional context, factor endowments and economic size.

Another important consideration to discuss is the one of Kuznets (1955), who emphasises that income inequality steeply augments at the early stages of development, reaches a peak, and then supposedly commences to decrease, as the economy gets through an industrialization process. Then, Kuznets's prediction concerns long-term change in inequality that are already controlled for by our dynamic approach. However, Latin America is a region that suffers from an inadequate development of the manufacturing sector (except Mexico) and where natural resource-based commodities are still dominant in its production and export basket. Hence, there are doubts whether Kuznets curve holds for Latin America. Nevertheless, a correct validation of the Kuznets's hypothesis would require a large sample of countries at different stages of the development process or to focus on one country that went through an industrialization process as proposed by Barro $(2000,2008)$. Then, our study aims at examining the role played by trade in the year-to year changes in income inequality within countries.

The model includes year fixed effects that control for all the events affecting in a similar manner the countries of our sample, such as the 2008 financial crisis. According to trade reforms, these countries have followed different trade liberalisation processes during the first part of the period analysed. Starting from the end of the 1990s, little changes have been introduced in this regard and trade policies may well be accurately controlled for, by year fixed effects. The dynamic specification, which includes the level of income inequality in the previous year, already account for the long term determinants of inequality, even if we are not able to precise which factors there are. Bearing in mind these circumstances, accurate additional control would be the variables that may influence trends in income inequality in the mid- and short term. For instance, it would be accurate to control for fiscal and labour policies but these data are difficult to gather in an accurate manner for our sample. We include GDP growth and 
the net barter terms of trade, defined as the ratio of exports to import prices, to account in particular for the expansion in the price of commodities after 2000. ${ }^{1}$

Our empirical baseline model takes the following form:

$$
I N E Q_{i t}=\alpha_{i t}+\beta I N E Q_{i, t_{-1}}+\operatorname{CTRADE} E_{i t}+D T_{t}+\sum \delta X_{i t}+\varepsilon_{i t}
$$

where $I N E Q_{i t}$ denotes the distribution of income measured by Gini coefficient in country $i$ where $i$ is one of the $11 \mathrm{LA}$ and $t$ indicates the year, while $I N E Q_{i, t_{-1}}$ is the lagged Gini coefficient in country $i$; TRADE $E_{i t}$ represents trade expressed as a share of GDP of country $i$ in year $t ; T_{t}$ denotes year dummies, $X_{i t}$ is a vector of control variables in country $i$ and year $t$, including GDP per capita and its square, GDP growth, FDI net inflow (\% of GDP) and terms of trade defined as the ratio of exports to import prices.

To obtain a deeper insight into the relationship between trade openness and income inequality in Latin America, we adopt a more disaggregated analysis of trade using several classifications of trade partners and nature of products. To this end, we distinguish among partners inside and outside Latin America to check the role of regional integration in this process. To account for the relative abundance in factors of LA countries compared with their trade partners, as suggested by Davis (1996), we also classify partners as higher, similar and lower-income countries according to the relative levels of income of the trading partners compared with the reporting income levels of Latin American countries. ${ }^{2}$

In a second step, we disaggregate trade flows by stage of production, namely agriculture goods, oil and mining goods, consumption goods, intermediate goods and equipment goods in order to test if the SBTC hypothesis holds for Latin America and to which extent its comparative advantage in the production of primary commodities contributes to a reduction in income inequality. SBTC indeed arises from the increase in trade in final goods and technology transfer (in the form of capital and intermediate goods) (see Acemoglu, 2003; Feenstra and Hanson, 1996; Murakami, 2014). Hence, we conjecture a negative impact of trade in consumption, intermediate, and equipment goods on inequality, conditional upon the technological differentials between trading partners. Regarding the region's comparative advantage in primary commodities, we predict two conflicting effects on inequality. Trade in agriculture goods reduces inequality as they are unskilled-labour intensive, while trade in oil and mining goods may worsen inequality as these goods are complementary to capital and skills (Székely and Mendoza, 2017).

\footnotetext{
${ }^{1}$ We have also tested the influence of inflation, real exchange rate and a dummy variable for the period 2000-2014 to account for commodity booms. Results are similar.

2 Our income level classifications are based on the difference between the GDP per capita (GDPpc) of country $i$ and the GDP per capita (GDPpc) of country $j$ in year $t$, where $i$ is a Latin American country and $j$ is a trading partner. Considering the percentiles 33 (p33) and 66 (p66) of the difference GDPpcit - GDPpcjt, we define $j$ as a higherincome partner if GDPpcit - GDPpcjt < p33, we define $j$ as a lower-income partner if GDPpcit - GDPpcjt $>$ p66 and

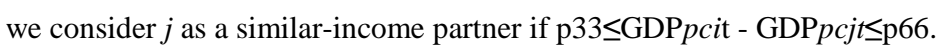


Then we disaggregate all trade flows into export and import to check if they have an asymmetric influence on inequalities as suggested by the literature review. In particular, the hypothesis of SBTC is mainly induced by the import channel. We predict overall exports to have an equalizing effect on inequality due to the region's concentration in the export of unskilled-labour intensive activities, or an increasing effect if technology catch-up hypothesis holds for Latin America through the exports of more skill-intensive goods (see Zhu and Trefler, 2005). Hence, we predict a deteriorating-inequality effect of the exports of intermediate and equipment goods, while the effect of the exports of consumption goods on inequality is not clear, depending on the skill intensity used in their production. We also conjecture that the exports of oil and mining goods worsen inequality due to complementary to capital and skills, while the exports of agriculture goods reduce it because they are unskilled-intensive. On the importing-side, we expect the effect of overall imports on inequality to depend on the technological level of trading partners, as discussed in the literature review section. We also predict that the imports of consumption (see Ffrench-Davis, 2010), intermediate and equipment goods raise inequality, depending on the technological level of trading partners. The imports of agriculture goods may boost inequality, as it would decline the demand for domestic unskilled labours, whereas the imports of oil and mining goods induce the opposite effect.

\section{$4 \quad$ Data}

Our sample accounts for 11 Latin American countries (Argentina, Bolivia, Brazil, Chile, Colombia, Ecuador, Mexico, Paraguay, Peru, Uruguay and Venezuela) and covers the 19892015 period. Summary statistics for all variables in study are in Table A.1 (Appendix).

Data on income inequality are imported from the Standardized World Income Inequality Database (SWIID). The control variables, including FDI inflow, GDP per capita, GDP growth, and net barter terms of trade are retrieved from the World Development Indicators, the World Bank. Trade/export/import variables and GDP are taken from Comptes Harmonisés sur les Échanges et l'Économie Mondiale (CHELEM) of the Centre d'Études Prospectives et d'Informations Internationales (CEPII).

Income inequality has experienced significant changes in Latin America during the last three decades as shown in Figure 1, which displays its evolution measured by Gini coefficient from 1990 to 2015. As can be observed, although there are considerable differences across countries, all Latin American countries have witnessed apparent declines in their inequality levels, starting from 2000 onwards. The countries with the highest income inequalities at the end of the period are Colombia (48.91), Chile (45.91), Mexico (45.87) and Peru (45.44). However, although the considerable reductions in income inequality, the average of Gini index in Latin America (46.8) is still higher than the average of Gini index in high-income countries (45.3) and low- and middle-income countries (41.5) during the late 2000s (UNDP, 2013). 
Figure 1: The evolution of Gini coefficient

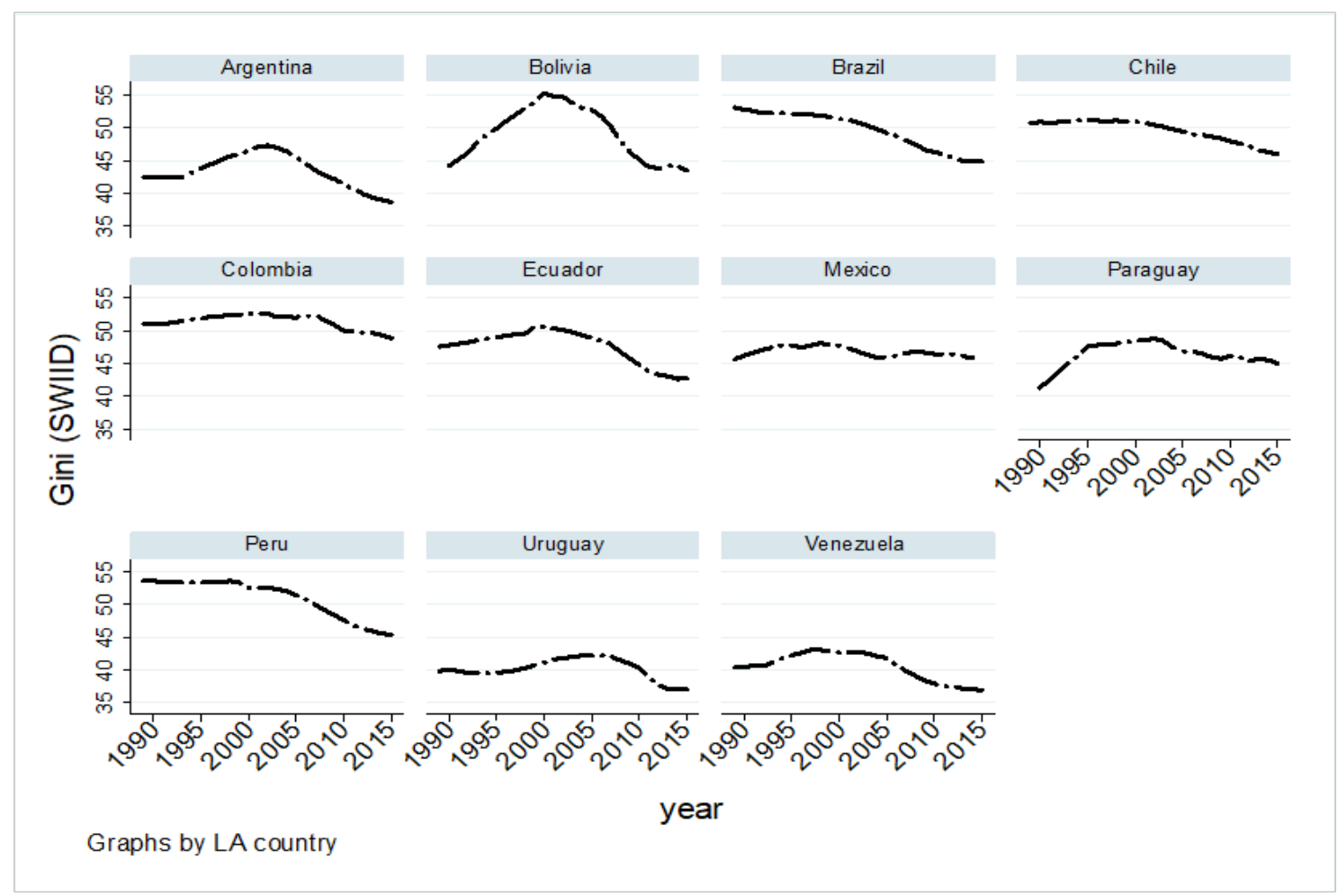

Source: the Standardized World Income Inequality Database (SWIID).

As can be gathered from Figure 2, Latin America trades mainly with countries with higherincome than themselves and, to a lesser extent with similar-income countries. More specifically, as shown in figure 3, trade with developed countries accounts for the largest share of Latin America's trade in equipment, oil and mining and agriculture products. In contrast, the weights of emerging and developed countries are almost balanced for intermediate and consumption goods.

Regarding the profiles of exports and imports, we disentangle in Figures 3 and 4, exports and imports of Latin American countries by products and groups of trading partners. Turning to intra-regional trade (Figure 3), exports to other Latin American countries account for a lower share than exports to non-Latin American countries. Similarly, the region is not the main source of imports of manufactured products. In contrast, almost all the primary products are imported from other Latin American countries. 
Figure 2: Latin America: trade by products and group of trading partners (\% of GDP), average 19892015

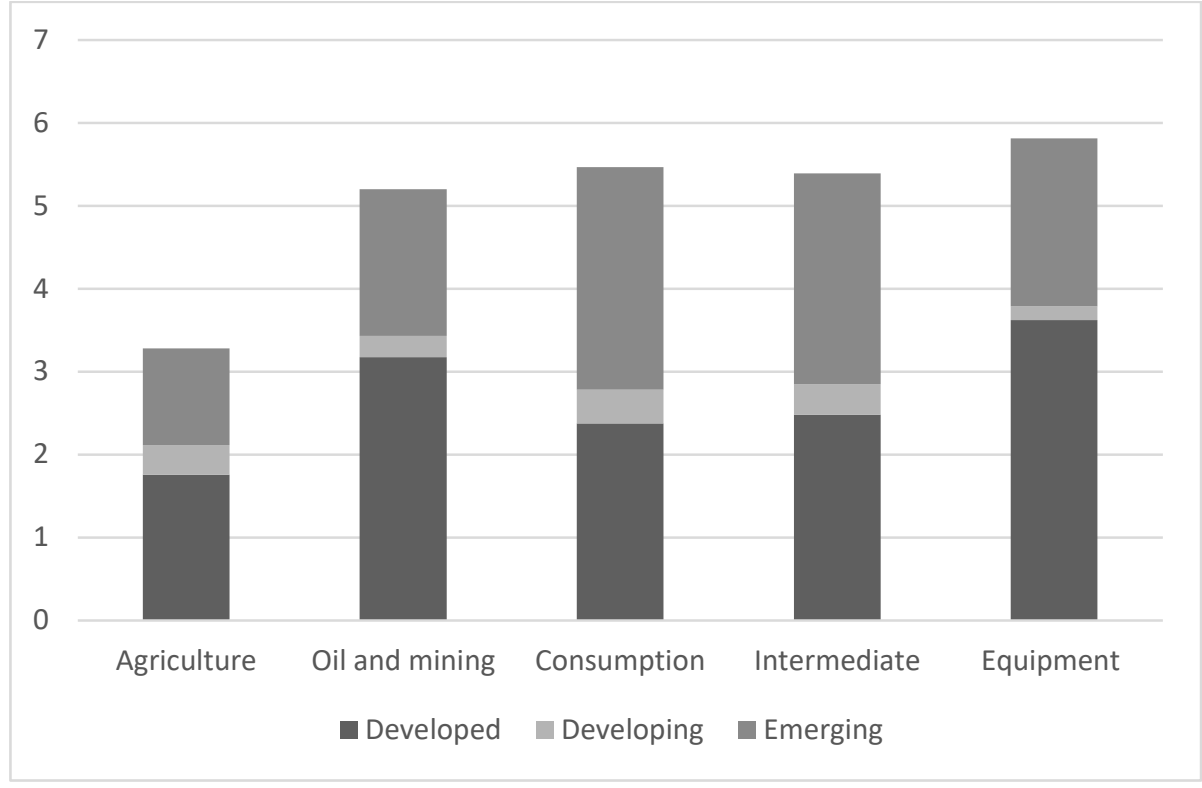

Source: CHELEM database, CEPII

Figure 3: Latin America: intra and extra-regional exports and imports by products (\% of GDP), average 1989-2015

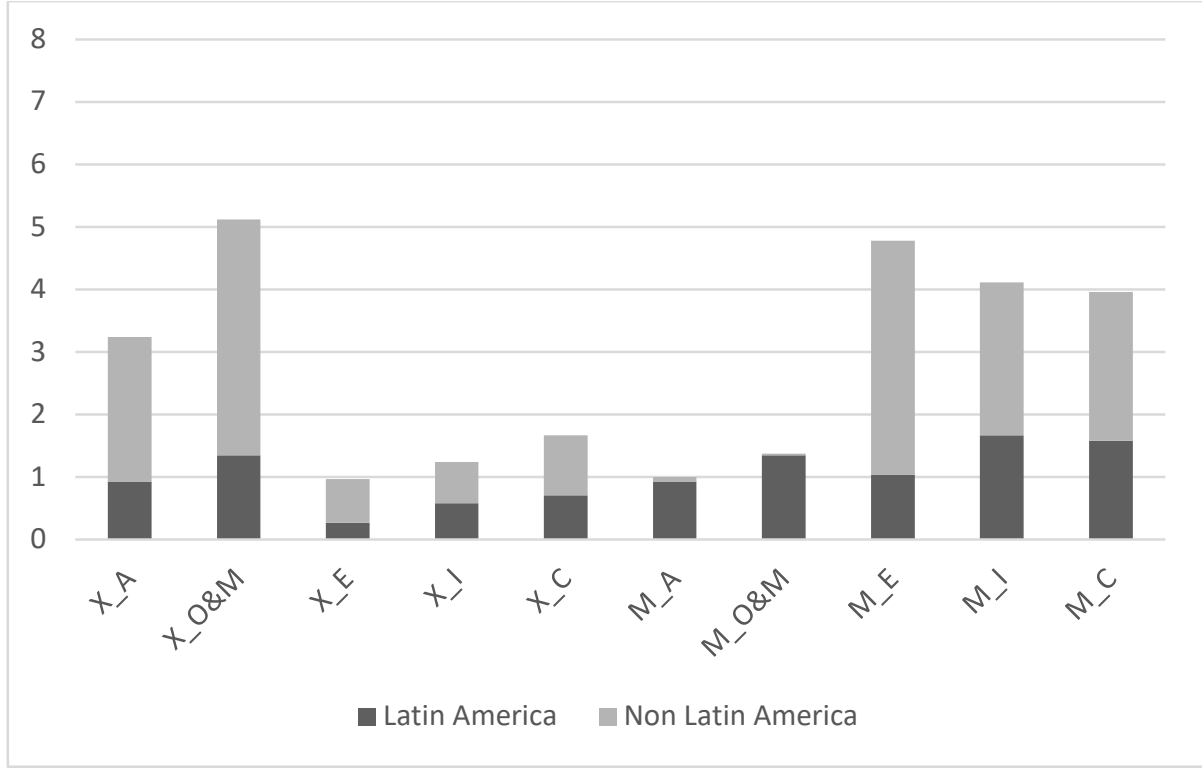

Source: CHELEM database, CEPII. Note: X_A: Agriculture exports; X_O\&M: Oil and mining exports; X_E: Equipment exports; X_I: Intermediate exports; X_C: Consumption exports. M_A: Agriculture imports; M_O\&M: Oil and mining imports; M_E: Equipment imports; M_I: Intermediate imports M_C: Consumption imports. 
To complete the picture, we detail exports and imports by products and group of trading partners (Figure 4). Figure A.1 displays the same information as Figure 4 for each Latin American country. The exports of oil and mining and agriculture products account for the largest share of the exports of Latin American countries. These primary products are sold mainly to developed countries and to a lesser extent to emerging countries (Figure 4). In particular, oil and mining exports are especially relevant (in terms of their GDP) for Venezuela, Bolivia, Ecuador and to a lesser extent for Colombia, Chile and Peru. The small countries of Paraguay and Uruguay export nearly agricultural goods. These products are also essential in the exports of Ecuador, Chile and to a lesser extent Argentina. The exporting patterns of Chile, Argentina, Brazil and above all Mexico are more diversified. In contrast of the other Latin American countries, exports of equipment, intermediates or consumption goods account for a significant share of their exports and GDP. Due to the polarization of the production and of the exports in the primary sector, the import basket of Latin American countries mainly include manufacturing goods they lack of, consumption, intermediates and equipment goods. Imports of consumption and intermediate goods come mainly from emerging countries and developed countries in similar shares while they purchase a larger share of equipment goods, more intensive in technology and skilled, in developed countries. Mirroring the specificities of Chile, Argentina, Brazil and Mexico underlined above, the weight of equipment goods in their imports

Figure 4: Latin America: exports and imports by products and group of trading partners (\% of GDP),average 1989-2015

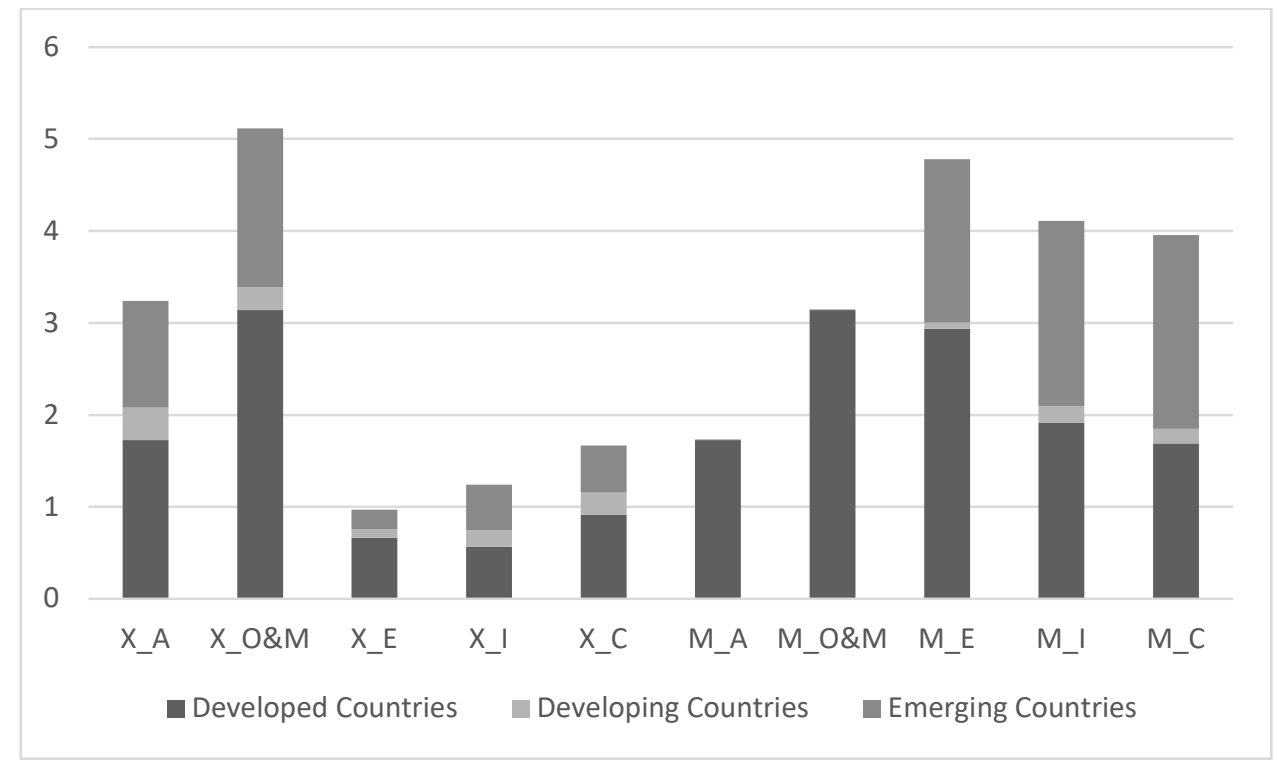

Source: CHELEM database, CEPII; Note: X_A: Agriculture exports; X_O\&M: Oil and mining exports; X_E: Equipment exports; X_I: Intermediate exports; X_C: Consumption exports. M_A: Agriculture imports; M_O\&M: Oil and mining imports; M_E: Equipment imports; M_I: Intermediate imports M_C: Consumption imports. 
is higher for these countries with a more diversified production. For every of these Latin American countries, imports come mainly from countries with higher income than themselves, while the destinations of exports are more diversified.

\section{$5 \quad$ Results Analysis}

All models have been estimated using panel data estimators with fixed effects and using difference GMM estimators (available upon request). Since both methodologies lead to similar results, we focus on the first one. In each table, there are 3 models: Models 1 report the results for trade flows regardless the partners, Models 2 display the results for trade flows within and outside Latin America and Models 3 contain the results for trade flows with higher-, similarand lower-income countries).

The results of our baseline model (the effect of overall trade and trade by partners) are presented in Table 1. Results for control variables are standard and similar in all the estimations. The lagged Gini index is highly significant mirroring the fact that inequality is a highly persistent phenomenon. Income inequality decreases with GDP per capita (statistically significant in Models 1 and 3) while the effect is lower for higher income (the squared value of GDP per capita displayed a negative coefficient). Our models point out a U-shaped relationship between inequality and the logarithm of per capita GDP. The minimum of this curve for all the

Table 1: Effects of overall trade and trade by partners (\% of GDP) on income inequality

\begin{tabular}{lccc}
\hline Dependant variable: Gini $_{\text {it }}$ & Model (1) & Model (2) & Model (3) \\
\hline Gini (t-1) & $0.896^{* * *}$ & $0.913^{* * *}$ & $0.879^{* * *}$ \\
Overall trade & -0.006 & & \\
Trade with (\% of GDP): & & & \\
Latin America (LA) & & $-0.03^{* * *}$ & \\
Others than Latin America (non- & & $0.016^{* * *}$ & \\
LA) & & & \\
Higher income countries (HIC) & & & $-0.013^{* * *}$ \\
Similar income countries(SIC) & & & $0.016^{*}$ \\
Lower income countries(LIC) & & $-3.777^{*}$ & $0.025^{*}$ \\
Ln (GDP per capita) & $-5.946^{* *}$ & 0.172 & -2.751 \\
Ln (GDP per capita) & & $-0.015^{* *}$ & 0.087 \\
GDP growth & $0.294^{* *}$ & $0.043^{* * *}$ & -0.009 \\
FDI inflow (\% of GDP) & -0.011 & -0.000 & $0.050^{* * *}$ \\
Term of trade & $0.059^{* * *}$ & 281 & -0.001 \\
$\mathrm{~N}$ & -0.000 & & 281 \\
\hline
\end{tabular}

Significant at $* \mathrm{p}<0.1 ; * * \mathrm{p}<0.05 ; * * * \mathrm{p}<0.01$. 
models is approximately 10. For our sample, the logarithm of per capita GDP ranges from 7.18 to 9.61. This means that the GDP of the countries in the sample are situated in the decreasing part of the curve. During the last years, inequality has declined in most of the countries of our sample in a period of significant growth. This empirical evidence is coherent with the negative sign obtained for GDP per capita when explaining income inequality. As argued in the Methodology section, our sample does not allow us to perform a test of Kuznets curve hypothesis (1955). Nonetheless, our results would be compatible with a situation where LA countries are situated in the second part of the inverted U shape Kuznets's curve, where the increase in income per capita translates into a decrease in the income dispersion. These results are consistent with the findings of Meschi and Vivarelli (2009), and Dreher and Gaston (2008).

As expected, GDP growth contributes to a reduction in income inequality (statistically significant in Models 3 and 4). FDI is statistically significant in all models and points out that openness to capital flows would accentuate income inequality, corroborating the empirical studies on Latin America (Herzer et al., 2014; Suanes, 2016). Terms of trade display a nonsignificance effect on income inequality in all models. This has an important meaning since it ensures us that the trend in prices, and in particular of commodity prices, are controlled for and do not exert a significant impact on GINI. Then, results are not an artefact of commodity boom that take place during the 2000-2014 period. Since these control variables have almost the same effects in all estimations, we only comment on the impact of trade variables in the following.

When the origin and destination of trade flows are not taken into account (Model 1), we find that trade does not induce any significant effect on income inequality in the region. This finding supports the hypothesis that aggregate trade flows uncover flows with heterogeneous intensities in production factors and would not capture, as argued Meschi and Vivarelli (2009), the role of transmission channels through which trade openness may affect income inequality within countries. Therefore, we split overall trade flows into trade within and outside Latin America (Model 2 in Table 1) and find that all the benefits in terms of reduction of inequality come from regional trade. On the opposite, trade with countries that do not belong to Latin America would worsen income inequality. In fact, Latin American countries trade more with partners located outside the region than within due to the relative similarities in the production structure and hence relative similarities in their comparative advantages (IMF, 2017). However, trade with partners located outside LA uncover very heterogeneous flows in terms of skill abundance intensities that prevent us to conclude that whether trade with all the partners outside the region would increase the income dispersion.

To fix this issue, we turn to a disaggregation of trade partners according to their income per capita level, used as a proxy of their capital intensity and relative abundance in human capital. We find that trade with higher-income countries attenuates inequality, whereas trade with both lower and similar-income countries accentuates income differences. This evidence corroborates the predictions of Davis (1996) concerning trade and inequality for developing countries: middle-income countries can see a rise in inequality, if they are unskilled-labour abundant by global standards and skilled-intensive abundant by Southern standards. This outcome is in line with Gourdon (2011), who evidences that South-South trade increases wage inequality, while trade with Northern countries leads to decreases it. The author ascribes his findings to the view that middle-income countries are considered as relatively skill-labour abundant in the SouthSouth relationship (as suggested by Davis, 1996); and secondly, to the fact that South-South 
leads to technological change that is biased toward more skill-intensive sectors, which brings about a larger impact on wage inequality, especially for lower-middle and low-income countries.

In Table 2, aggregated trade is split into exports and imports, regardless partners (Model 1) and by destination/origin (Models 2 and 3). Our results tend to show that the mechanism through which trade decreases inequality transits through exports more than through the import channel and indicate that the destinations of exports matter for inequalities. This is an important result because the literature has focused more on the latter more than on the former, based on the idea that foreign competition could boost productivity through a more efficient assignation of resources among sectors, but also because access to a wide variety of capital and intermediate products boosts technology transfers. We find that exports to other LA countries or to partners with higher income per capita would contribute to a reduction of income inequality. In contrast, the exports to other destination have no significant effect. More interestingly, none of these flows exacerbates inequalities. Remarkably, imports have no significant effect on inequality overall. However, imports from LA countries are found to tighten inequality, while imports from non-LA and similar-income countries would contribute to a more polarized distribution of income.

Table 2: Effects of overall exports and imports (\% of GDP) on income inequality

\begin{tabular}{|c|c|c|c|}
\hline $\begin{array}{l}\text { Dependant variable: } \\
\text { Gini }_{\text {it }}\end{array}$ & Model (1) & Model (2) & Model (3) \\
\hline Gini $(-1)$ & $0.896 * * *$ & $0.916^{* * *}$ & $0.880 * * *$ \\
\hline Exports & $-0.015^{* * *}$ & & \\
\hline Imports & 0.010 & & \\
\hline Exports (LA) & & $-0.029 * * *$ & \\
\hline Exports (non-LA) & & 0.003 & \\
\hline Imports (LA) & & $-0.039 * * *$ & \\
\hline Imports (non-LA) & & $0.037 * * *$ & \\
\hline Exports (HIC) & & & $-0.017 * * *$ \\
\hline Exports (SIC) & & & -0.002 \\
\hline Exports (LIC) & & & 0.017 \\
\hline Imports (HIC) & & & -0.002 \\
\hline Imports (SIC) & & & $0.033 * *$ \\
\hline Imports (LIC) & & & 0.036 \\
\hline Ln (GDP per capita) & $-5.538 * *$ & -3.154 & -2.577 \\
\hline Ln (GDP per capita) ${ }^{2}$ & $0.268 * *$ & 0.140 & 0.080 \\
\hline GDP growth & $-0.013^{*}$ & $-0.017 * *$ & -0.012 \\
\hline FDI inflow (\% of GDP) & $0.055^{* * *}$ & $0.041^{* * *}$ & $0.047 * * *$ \\
\hline Term of trade & -0.000 & 0.000 & -0.000 \\
\hline $\mathrm{N}$ & 281 & 281 & 281 \\
\hline
\end{tabular}

Significant at $* \mathrm{p}<0.1 ; * * \mathrm{p}<0.05 ; * * * \mathrm{p}<0.01$. 
A possible explanation for the negative nexus between imports from LA countries and inequality comes from the similarities among these partners in their endowments and technologies. In fact, regional trade among LA countries is shaped by trade agreements (Acosta and Montes-Rojas, 2008), such as Mercosur between Argentina, Brazil and Uruguay, and Andean, which includes Bolivia, Colombia, Ecuador and Peru, rather than comparative advantages. Trade among these countries consists in similar goods with similar intensities. However, unlike trade with other middle-income countries outside LA, trade among LA countries is not as skill-intensive as with other middle-income countries. Then, the effect of imports from other LA may boost the income of the poorest more than the ones of the richest. On the other hand, the positive association between imports from non-LA and inequality is driven by the influence of imports from other similar countries. Overall, imports from higher income countries have a negative but non-significant effect while the effect of imports from SIC worsens inequality. It stems from the fact that the region's imports basket from outside is mainly concentrated in relatively skill-intensive goods (ECLAC, 2015). This, in turn, favours skilled labours over unskilled labours and thus rises inequality (Ing, 2009). In the case of similar-income countries, the effect on inequality is expected as imports from these countries may contain skill-enchasing effect on income inequality (see Gourdon, 2011; Meschi and Vivarelli, 2009).

Finally, we analyse trade by type of products (Table A.2 and Table A.3 in Appendix). Trade in oil and mining goods is the only type of trade that really impacts income inequality in the region and this effect is driven by exports of these products, and in particular by exports to other Latin American countries. ${ }^{3} 4$ In the same line, importing these products from countries of the region propel income inequality. In this case, and since these products are mainly traded on an inter-industry basis, the effect may not transit through a decline in the skill premium but mainly represents the important increase in revenue obtained from exports of these primary products even if the pure price effect is controlled for by time fixed effects and terms of trade. There is also another possible channel transiting through FDI. Indeed, oil and mining sector has attracted foreign capital following trade reforms in many countries in the region (Suanes, 2016). According to Jensen and Rosas (2007), foreign capital may have two conflicting influence on income inequality in the host country. First, the competition between foreign capital and local capital increases the wages of local labours and hence reducing inequality. Second, foreign capital may decrease inequality, if foreign firms hire unskilled labours and pay wage premiums for them. Unfortunately, it is beyond the scope of this study to test this indirect effect.

As regards consumption goods, trade of these products within Latin America would be inequality reducing, while trade with third countries would have the opposite effect. In fact, the region implemented significant tariff cuts on consumption goods following trade reforms. The net effect of trade in these goods on the skill premium therefore depends on their skill level or industry affiliation (Porto, 2006 and Ural Marchand, 2017). A conjecture for that finding is that

\footnotetext{
3 All the 11 countries considered export oil or mining products.

4 Trade in agriculture goods induces decreasing effects on income inequality (trade within Latin America, similarand lower-income countries,). This can be attributed to the acceleration in the importance of primary goods in global markets, which led to an increase in their relative prices, employment expansion and eventually reduce income inequality (IMF, 2018).
} 
tariff changes induced by Mercosur on consumption goods have contributed to an increase in the relative price of unskilled-intensive goods (mainly the price of "food and beverage" consumption goods). This, in turn, has led to increase the wages of unskilled labours over skilled labours (Porto, 2006). On the other hand, a possible explanation for why trade in consumption goods with non-Latin American countries increases income inequality is that the decreases in the region's protection level had a significant impact on the composition of its imports from non-Latin American countries with a shift in the imports of non-traditional products. For example, Ffrench-Davis (2010) observes that trade openness has led to a rapid rise in the imports of "non-food" consumption goods in Chile and Reinert (2007) reports an increase in the import of high-tech durable consumer goods in Peru.

Another important feature of the intra-regional trade is that exports of agricultural products to the region and imports of consumption goods from the region decrease inequalities. We conjecture that the first result is explained by the fact that the production of these goods intensively depends on unskilled-labour (Székely and Mendoza, 2017). In the second case, imports of consumption products from LA countries contribute to reducing disparities in income, which may be explained by the fact that cheaper products alleviate the budget of poor households. In this vein, Marchand (2017) suggests that the distributional effects of the imports of consumption goods depend on the extent to which these goods are important in the budget of poor households and on their prices in global markets. The results also show that the export of consumption goods to lower-income countries (Table A.3, Model 3) aggravates income inequality, while the exports to other partners have no significant effect. Indeed, the distributional effect here on income inequality depends on the type of labour intensively used in the production (low, medium or high-skilled labour). Hence, an increase in the demand for consumption goods by lower-income countries would lead to increase the returns to this factor over others. We hypothesize that exports to these lower-income countries exert a high pressure on unskilled-labour wages, if they compete with local demand, or an upward pressure on the wages of skilled-labour. If in the opposite, LA export goods relatively skill-intensive in line with their intermediate position in terms of endowments.

Notice that trade with a relatively higher-income partner decreases income inequality. The results disaggregated by products displayed in Tables A.2 and A.3 shed some new lights on this result. Neither exports to higher-income countries nor imports from these partners for most products have a significant impact on inequality. This reducing effect on inequality is exclusively explained by trade in oil and mining goods and, in particular, the exports of these goods. Then, trade of manufactured goods with higher-income countries have no effect on inequalities. In particular, imports of equipment goods or intermediate goods that should bring some important technology transfers have no direct effect on this outcome.

In the manufacture sector, we have already underlined that imports of consumption goods from LA countries decrease inequalities and export to lower income countries would exacerbate this dispersion. Regarding equipment goods, the effects are almost not statistically significant. ${ }^{5}$ Apart from this, the only flows that drive some effects on the dispersion of income in Latin America are the exports of intermediate goods to similar-income countries that boost

\footnotetext{
5 Exports and imports treated separately have no significant effect. Exports of equipment goods to similar-income countries induce a reduction in income inequality but are fairly significant.
} 
inequalities. The effect of exporting these goods on inequality indeed depend on the skill composition used in their production. Chang (2017) finds evidence indicating that the trade of final products and parts and components inside Latin America and their sophistication levels have improved due to the growth in the importation of machinery parts and components from several regions around the world, especially from North America and East Asia. This, in turn, requires a more intensive use of skilled labours that would explain this effect.

\section{Conclusion}

To assess the effects of trade openness on income inequality, we use a dynamic panel approach to take into account the high persistent behaviour of income inequality for 11 Latin American countries, during the period 1989-2015. Then, unlike most previous studies, we fully account for all the effects that may have influenced income inequality in the past. Our estimates of the effect of trade on income inequality represent only the direct effect of current trade and would, if anything, underrate this effect. We go deep into the nature of trade and partners by considering trade inside and outside Latin America and partners' income levels to take differences in capital intensities into account. Finally, we adopt a more disaggregated analysis of trade, exports and import of production by stages, including agriculture goods, oil and mining goods, consumption goods, intermediate goods and equipment goods, which enables us to identify the different potential channels through which trade may affect income inequality.

We find that overall trade flows do not significantly affect income inequality in Latin America. When we account for the direction of trade taking into account the income level of trading partners, we find that trade with partners that enjoy a higher income per capita reduces the dispersion of income, whereas trade with similar- and lower-income countries leads to a rise in inequality. As regard trade by stage of production, we find that trade in primary goods and trade in consumption have a more obvious effect than trade in intermediate and equipment goods. Trade in primary commodities moderates inequality in Latin American countries in the period analysed, even when the improvement in the terms of trade is controlled for. Regional trade in consumption goods decreases inequality, while trade in consumption goods with nonLatin American countries harms inequality.

Our empirical analysis highlights a more salient effect on income inequality for, the export channel rather than for the import channel. In general, the exports of agriculture and oil and mining contribute to attenuate income inequality, while imports of these goods enhance the opposite effect. As predicted by the Stolper-Samuelson effect, the specialisation according to comparative advantages that accompany trade openness would raise the return of the factor intensively used. What is more surprising is that our empirical findings emphasise a more significant role of the export channel, while the import channel has received more attention in the literature and raises more expectations in terms of benefits to be obtained from trade. Our results hence confirm that the consequences of trade openness depend on how countries are integrated into the international economic system (Mcmillan et al., 2014). Given the fact that Latin America is abundant in natural resource-based commodities, Mcmillan et al. (2014) suggest that the abundance in natural resources and primary products lowers the motivation for 
transition toward modern industries and enhances traditional production patterns. This argument is linked to the extensive strand of the literature studying the negative effects of substantial natural resources endowment on countries' performance, which may turn the "blessing” of natural resources into a "curse" since productive activities that boost growth decline in favour of natural resources sector for rent-seeking purposes (Sachs and Warner, 2001). This argument mirror the position of IMF (2017) according to which the commodity price boom would have prevented Latin American countries to shift the production of more skill-intensive goods.

From a more general perspective, our results confirm that income inequality which is a highly persistence phenomenon. This calls for other policies more directed through a restructuration of the production but also the need for social and education policies that directly influence income inequality. As far as trade policies are concerned, our study finds no evidence of a detrimental effect of trade on income inequalities. More interestingly, this paper stresses the role of exports to contribute to a reduction of income inequalities, a question that has been largely overlooked by the literature. Then, our findings provide some evidence for the policy debate and promising avenue for future research.

\section{References}

Acemoglu, D. (2003). Patterns of skill premia. The Review of Economic Studies, 70(2), 199-230. https://ideas.repec.org/a/oup/restud/v70y2003i2p199-230.htm l

Acosta, P., and Montes-Rojas, G.V. (2008). Trade reform and inequality: The case of Mexico and Argentina in the 1990s. World Economy, 31(6), 763-780.

https://onlinelibrary.wiley.com/doi/abs/10.1111/j.1467-9701.2008.01100.x

Alstadsæter, A., Johannesen, N., and Zucman, G. (2018). Who owns the wealth in tax havens? Macro evidence and implications for global inequality. Journal of Public Economics, 162, 89-100. https://www.sciencedirect.com/science/article/abs/pii/S0047272718300082

Alvaredo, F., Chancel, L., Piketty, T., Saez, E., and Zucman, G. (2017). Global inequality dynamics: New findings from WID. world. American Economic Review, 107(5), 404-409. https://www.aeaweb.org/articles?id=10.1257/aer.p20171095

Anand, S., and Segal, P. (2015). The global distribution of income. In Handbook of income distribution (Vol. 2, pp. 937-979).

Arellano, M., and Bond, S. (1991). Some test of specification for panel data: Monte Carlo evidence and an application to employment equations. Review of Economic Studies, 58(2), 277-297. https://ideas.repec.org/a/oup/restud/v58y1991i2p277-297..html

Arribas, I., Pérez, F., and Tortosa-Ausina, E. (2009). Measuring globalization of international trade: Theory and evidence. World Development, 37(1), 127-145. https://www.sciencedirect.com/science/article/abs/pii/S0305750X08001447 
Atolia, M. (2007). Trade liberalization and rising wage inequality in Latin America: Reconciliation with HOS theory. Journal of International Economics, 71(2), 467-494.

https://www.sciencedirect.com/science/article/abs/pii/S0022199606001085

Atkinson, A.; Piketty, T., and Saez, E. (2011). Top incomes in the long run of history. Journal of Economic Literature, 49(1), 3-71. https:/www.aeaweb.org/articles?id=10.1257/jel.49.1.3

Attanasio, O., Goldberg, P.K., and Pavcnik, N. (2004). Trade reforms and wage inequality in Colombia. Journal of Development Economics, 74(2), 331-366.

https://www.sciencedirect.com/science/article/abs/pii/S0304387804000185

Barro, R.J. (2000). Inequality and growth in a panel of countries. Journal of Economic Growth, 5(1), 5-32. https://www.jstor.org/stable/40216021

Barro, R.J. (2008). Inequality and growth revisited. Working Papers on Regional Economic Integration 11, Asian Development. https://ideas.repec.org/p/ris/adbrei/0011.html

Behrman, J.R., Birdsall, N., and Székely, M. (2007). Economic policy changes and wage differentials in Latin America. Economic Development and Cultural Change, 56(1), 57-97. https://www.jstor.org/stable/10.1086/520556

Brambilla, I., and Porto, G.G. (2016). High-income export destinations, quality and wages. Journal of International Economics, 98, 21-35. https://www.sciencedirect.com/science/article/abs/pii/S0022199615001439

Brambilla, I., Lederman, D., and Porto, G. (2012). Exports, export destinations, and skills. American Economic Review, 102(7), 3406-3438. https://www.aeaweb.org/articles?id=10.1257/aer.102.7.3406

Brambilla, I., Lederman, D., and Porto, G. (2019). Exporting firms and the demand for skilled tasks. Canadian Journal of Economics, 52(2), 763-783. https://onlinelibrary.wiley.com/doi/abs/10.1111/caje.12382

Bustos, P. (2011a). Trade liberalization, exports, and technology upgrading: Evidence on the impact of MERCOSUR on Argentinian firms. American Economic Review, 101(1), 304-340. https://ideas.repec.org/a/aea/aecrev/v101y2011i1p304-40.html

Bustos, P. (2011b). The impact of trade liberalization on skill upgrading. Evidence from Argentina. Economics Working Papers 1189, Department of Economics and Business, Universitat Pompeu Fabra.

Chang, M.S. (2017). Machinery production networks in Latin America: A quantity and quality analysis. Latin American Economic Review, 26(9).

https://link.springer.com/article/10.1007/s40503-017-0054-5

Conte, A., and Vivarelli, M. (2011). Imported skill-biased technological change in developing countries. The Developing Economies, 49(1), 36-65.

https://onlinelibrary.wiley.com/doi/abs/10.1111/j.1746-1049.2010.00121.x

Crinò, R. (2012). Imported inputs and skill upgrading. Labour Economics, 19(6), 957-969. https://www.sciencedirect.com/science/article/abs/pii/S0927537112000796

Davis, D.R. (1996). Trade liberalization and income distribution. National Bureau of Economic Research (NBER), Working Paper, 5693. https://ideas.repec.org/p/nbr/nberwo/5693.html 
Dreher, A., and Gaston, N. (2008). Has globalization increased inequality? Review of International Economics, 16(3), 516-536.

https://onlinelibrary.wiley.com/doi/abs/10.1111/j.1467-9396.2008.00743.x

Economic Commission for Latin America and the Caribbean (ECLAC) (2015). Latin America and the Caribbean in the World Economy, (LC/G.2650-P), Santiago, Chile.

Feenstra, R.C., and Hanson, G. H. (1996). Globalization, outsourcing, and wage inequality. American Economic Review, 86(2), 240-245. https://ideas.repec.org/a/aea/aecrev/v86y1996i2p240-45.html

Fernandes, A.M., and Paunov, C. (2013). Does trade stimulate product quality upgrading? Canadian Journal of Economics, 46(4), 1232-1264.

https://onlinelibrary.wiley.com/doi/abs/10.1111/caje.12047

Ferreira, F.H., Leite, P.G., and Wai-Poi, M. (2007). Trade liberalization, employment flows, and wage inequality in Brazil. World Bank Policy Research Working Paper No. 4108, The World Bank, Washington, D.C. https://papers.ssrn.com/sol3/papers.cfm?abstract_id=956488

Ffrench, D. (2010). Economic reforms in Chile: From dictatorship to democracy, $2^{\text {nd }}$ edition, Basingstoke, Hampshire; New York: Palgrave Macmillan.

Galiani, S., and Porto, G.G. (2010). Trends in tariff reforms and in the structure of wages. The Review of Economics and Statistics, 92(3), 482-494. https://ideas.repec.org/a/tpr/restat/v92y2010i3p482-494.html

Gasparini, L., and Lustig, N. (2011). The rise and fall of income inequality in Latin America. Working Papers 1110, Tulane University, Department of Economics. https://ideas.repec.org/p/tul/wpaper/1110.html

Gasparini, L., Galiani, S., Cruces, G., and Acosta, P. (2011). Educational upgrading and returns to skills in Latin America: Evidence from a supply-demand framework, 1990-2010. Policy Research Working Paper 5921. The World Bank.

Goldberg, P.K., and Pavcnik, N. (2007). Distributional effects of globalization in developing countries. Journal of Economic Literature, 45(1), 39-82. https://www.aeaweb.org/articles?id=10.1257/jel.45.1.39

Gonzaga, G., Menezes Filho, N., and Terra, C. (2006). Trade liberalization and the evolution of skill earnings differentials in Brazil. Journal of International Economics, 68(2), 345-367. https://www.sciencedirect.com/science/article/abs/pii/S0022199605000954

Gourdon, J. (2011). Wage inequality in developing countries: South-South trade matters. International Review of Economics, 58(4), 359-383. https://ideas.repec.org/a/spr/inrvec/v58y2011i4p359-383.html

Hanson, G.H., and Harrison, A. (1999). Trade liberalization and wage inequality in Mexico. Industrial and Labor Relations Review, 52(2), 271-288. https://www.jstor.org/stable/2525166

Harrison, A., McLaren, J., and McMillan, M.S. (2010). Recent findings on trade and inequality. NBER Working Papers 16425, National Bureau of Economic Research. https://ideas.repec.org/p/nbr/nberwo/16425.html

Hartmann, D., Guevara, M.R., Jara-Figueroa, C., Aristarán, M., and Hidalgo, C.A. (2017). Linking economic complexity, institutions, and income inequality. World Development, 93(C), 75-93. https://ideas.repec.org/a/eee/wdevel/v93y2017icp75-93.html 
Herzer, D., Hühne, P., and Nunnenkamp, P. (2014). FDI and income inequality - Evidence from Latin American Economies. Review of Development Economics, 18(4), 778-793. https://onlinelibrary.wiley.com/doi/abs/10.1111/rode.12118

Ing, L.Y. (2009). Lower tariff, rising skill premium in developing countries: Is it a coincidence? World Economy, 32(7), 1115-1133. https://onlinelibrary.wiley.com/doi/abs/10.1111/j.1467-9701.2009.01192.x

IMF (2017). Cluster report: Trade integration in Latin America and the Caribbean (2017). IMF Staff Country Reports 17/66, International Monetary Fund. https://ideas.repec.org/p/imf/imfscr/17-66.html

IMF (2018). 5. Poverty and inequality in Latin America: Gains during the commodity boom but an uncertain outlook. In Regional economic outlook, April 2018, Western Hemisphere Department: Seizing the Momentum, International Monetary Fund.

Jaumotte, F., Lall, S., and Papageorgiou, C. (2013). Rising income inequality: Technology, or trade and financial globalization? IMF Economic Review, 61(2), 271-309. https://ideas.repec.org/a/pal/imfecr/v61y2013i2p271-309.html

Jensen, N.M., and Rosas, G. (2007). Foreign direct investment and income inequality in Mexico, 1990-2000. International Organization, 61(3), 467-487. https://www.jstor.org/stable/4498155

Kasahara, H., Liang, Y., and Rodrigue, J. (2016). Does importing intermediates increase the demand for skilled workers? Plant-level evidence from Indonesia. Journal of International Economics, 102, 242-261. https://www.sciencedirect.com/science/article/pii/S0022199616300861

Kuznets, S. (1955). Economic growth and income inequality. The American Economic Review, 45(1), 1-28. https://assets.aeaweb.org/asset-server/files/9438.pdf

Lopez-Calva, L.F., Lustig, N., and Ortiz-Juarez, E. (2015). A long-term perspective on inequality and human development in Latin America. Journal of Human Development and Capabilities, 16(3), 319-323. https://ideas.repec.org/a/taf/jhudca/v16y2015i3p319-323.html

López-Calva, L.F., and Lustig, N. (2010). Explaining the decline in inequality in Latin America: Technological change, educational upgrading and democracy. Declining Inequality in Latin America: A decade of progress, 1-24.

Lustig, N., López-Calva, L.F., and Ortiz-Juárez, E. (2013). Declining inequality in Latin America in the 2000s: The cases of Argentina, Brazil, and Mexico. World Development, 44, 129-41. https://www.sciencedirect.com/science/article/abs/pii/S0305750X12002276

Matsuyama, K. (2007). Beyond icebergs: Towards a theory of biased globalization. The Review of Economic Studies, 74(1), 237-253. https://www.jstor.org/stable/4123243

Mcmillan, M., Rodrik, D., and Verduzco-Gallo, I. (2014). Globalization, structural change, and productivity growth, with an update on Africa. World Development 63, 11-32. https://ideas.repec.org/a/eee/wdevel/v63y2014icp11-32.html

Meschi, E., and Vivarelli, M. (2009). Trade and income inequality in developing countries. World Development, 37(2), 287-302. https://ideas.repec.org/a/eee/wdevel/v37y2009i2p287-302.html 
Murakami, Y. (2014). Trade liberalization and skill premium in Chile. México y la Cuenca del Pacífico, 3(6), 77-101.

http://www.scielo.org.mx/scielo.php?script=sci_abstract\&pid=S2007-

53082014000100077\&lng=pt\&nrm=iso\&tlng=en

Papanek, G., and Kyn, O. (1986). The effect on income distribution of development, the growth rate and economic strategy. Journal of Development Economics, 23(1), 55-65. https://www.sciencedirect.com/science/article/abs/pii/0304387886900799

Pavcnik, N. (2017). The impact of trade on inequality in developing countries. NBER Working Paper No. 23878. National Bureau of Economic Research. https://www.nber.org/papers/w23878

Pavcnik, N., Blom, A., Goldberg, P., and Schady, N. (2004). Trade liberalization and industry wage structure: Evidence from Brazil. The World Bank Economic Review, 18(3), 319-344. https://ideas.repec.org/a/oup/wbecrv/v18y2004i3p319-344.html

Piketty, T. (2001). Les hauts revenus en France au 20eme siècle - Inégalités et redistributions, 1901-1998. Paris: Editions Grasset.

Piketty, T., and Saez, E. (2003). Income inequality in the United States, 1913-1998. The Quarterly Journal of Economics, 118(1), 1-41. https://academic.oup.com/qje/article/118/1/1/1917000

Porto, G. (2006). Using survey data to assess the distributional effects of trade policy. Journal of International Economics, 70(1), 140-160. https://doi.org/10.1016/j.jinteco.2005.09.003

Reinert, E.S. (Ed.). (2007). Globalization, economic development and inequality: An alternative perspective. Edward Elgar Publishing.

Reyes, J., Schiavo, S., and Fagiolo, G. (2010). Using complex networks analysis to assess the evolution of international economic integration: The cases of East Asia and Latin America. The Journal of International Trade \& Economic Development, 19(2), 215-239. https://www.tandfonline.com/doi/abs/10.1080/09638190802521278

Robbins, D. (2003). The impact of trade liberalization upon inequality in developing countries - a review of theory and evidence. ILO Working Papers 993650553402676, International Labour Organization. https://ideas.repec.org/p/ilo/ilowps/993650553402676.html

Rodríguez-Pose, A., and Gill, N. (2006). How does trade affect regional disparities? World Development, 34(7), 1201-1222.

https://www.sciencedirect.com/science/article/abs/pii/S0305750X0600060X

Roodman, D. (2009). How to do xtabond2: An introduction to difference and system GMM in Stata. Stata Journal, 9(1), 86-136. https://ideas.repec.org/a/tsj/stataj/v9y2009i1p86-136.html

Sachs, J.D., and Warner, A.M. (2001). The curse of natural resources. European Economic Review, 45 (4-6), 827-838. https://www.sciencedirect.com/science/article/pii/S0014292101001258

Sánchez-Páramo, C., and Schady, N. (2003). Off and running? Technology, trade, and the rising demand for skilled workers in Latin America. Policy Research Working Paper Series 3015, The World Bank. https://ideas.repec.org/p/wbk/wbrwps/3015.html

Solt, F. (2016). The standardized world income inequality database. Social Science Quarterly, 97(5), 1267-1281. https://onlinelibrary.wiley.com/doi/full/10.1111/ssqu.12295 
Stolper, W.F., and Samuelson, P.A. (1941). Protection and real wages. The Review of Economic Studies, 9(1), 58-73. https://www.jstor.org/stable/2967638

Suanes, M. (2016). Foreign direct investment and income inequality in Latin America: A sectoral analysis. Cepal Review Review, 118, 45-61. https://www.cepal.org/en/publications/40435-foreign-direct-investment-and-income-inequalitylatin-america-sectoral-analysis

Székely, M., and Mendoza, P. (2015). Is the decline in inequality in Latin America here to stay? Journal of Human Development and Capabilities, 16(3), 397-419. https://ideas.repec.org/a/taf/jhudca/v16y2015i3p397-419.html

Székely, M., and Mendoza, P. (2017). Declining inequality in Latin America: Structural shift or temporary phenomenon? Oxford Development Studies, 45(2), 204-221.

https://ideas.repec.org/a/taf/oxdevs/v45y2017i2p204-221.html

UNDP (2013). Humanity divided: Confronting inequality in developing countries. United Nations Development Programme, New York.

Ural Marchand, B. (2017). How does international trade affect household welfare? IZA World of Labor, Institute of Labor Economics (IZA), August.

https://ideas.repec.org/a/iza/izawol/journl2017n378.html

Verhoogen, E.A. (2008). Trade, quality upgrading, and wage inequality in the Mexican manufacturing sector. The Quarterly Journal of Economics, 123(2), 489-530. https://academic.oup.com/qje/article/123/2/489/1930844

Wang, Y., and Yin, X. (2016). Technology transfer, welfare, and wage inequality. Review of Development Economics, 20(2), 611-623. https://onlinelibrary.wiley.com/doi/abs/10.1111/rode.12250

Wood, A. (1995a). How trade hurt unskilled workers. Journal of Economic Perspectives, 9(3), 57-80. https://www.aeaweb.org/articles?id=10.1257/jep.9.3.57

Wood, A. (1995b). North-South trade, employment, and inequality: Changing fortunes in a skill-driven world. Oxford University Press.

Wood, A. (1997). Openness and wage inequality in developing countries: The Latin American challenge to East Asian conventional wisdom. The World Bank Economic Review, 11(1), 33-57. https://www.jstor.org/stable/3990218

World Bank (2014). Social gains in the balance: A fiscal policy challenge for Latin America and the Caribbean (English). Latin America and the Caribbean poverty and labor brief. World Bank Group.

http://documents.worldbank.org/curated/en/393651468276880855/Social-gains-in-the-balance-afiscal-policy-challenge-for-Latin-America-and-the-Caribbean

Zhu, S. C., and Trefler, D. (2005). Trade and inequality in developing countries: A general equilibrium analysis. Journal of International Economics, 65(1), 21-48.

https://www.sciencedirect.com/science/article/abs/pii/S0022199604000200 


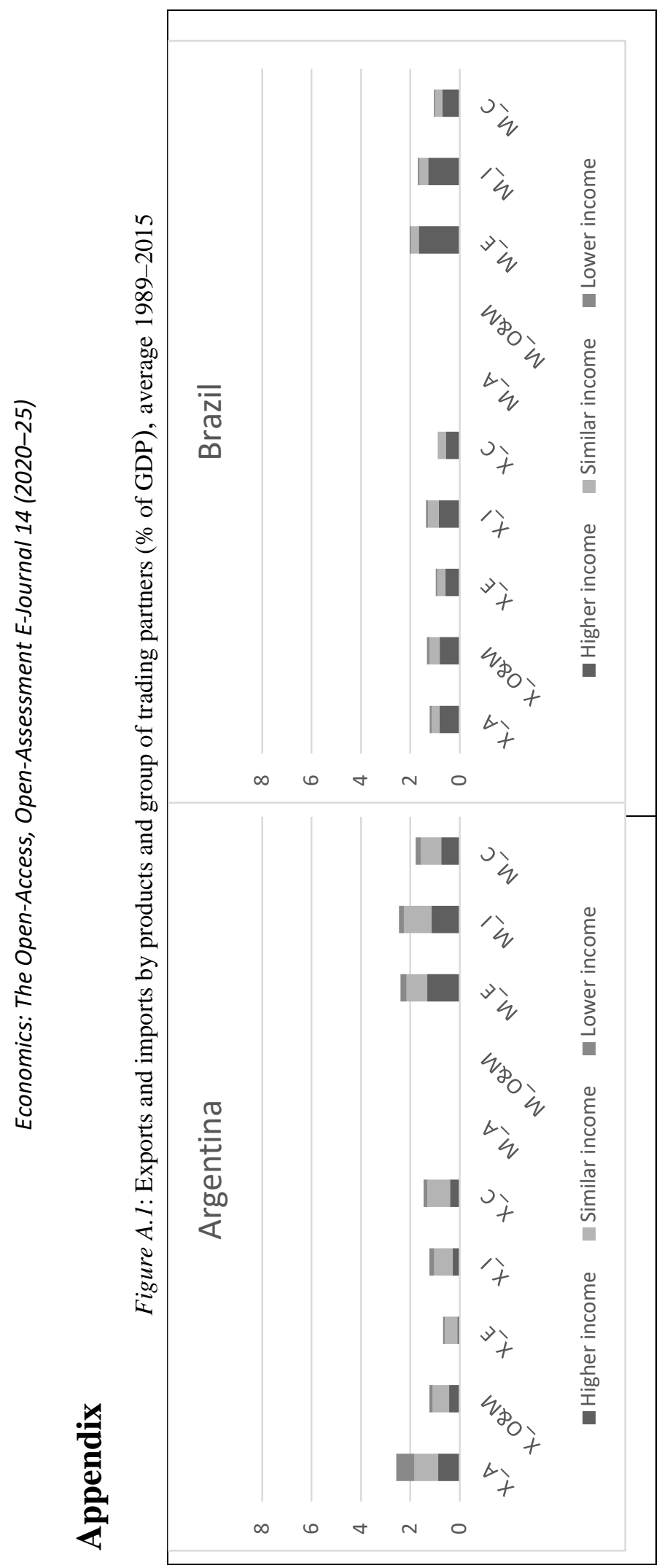




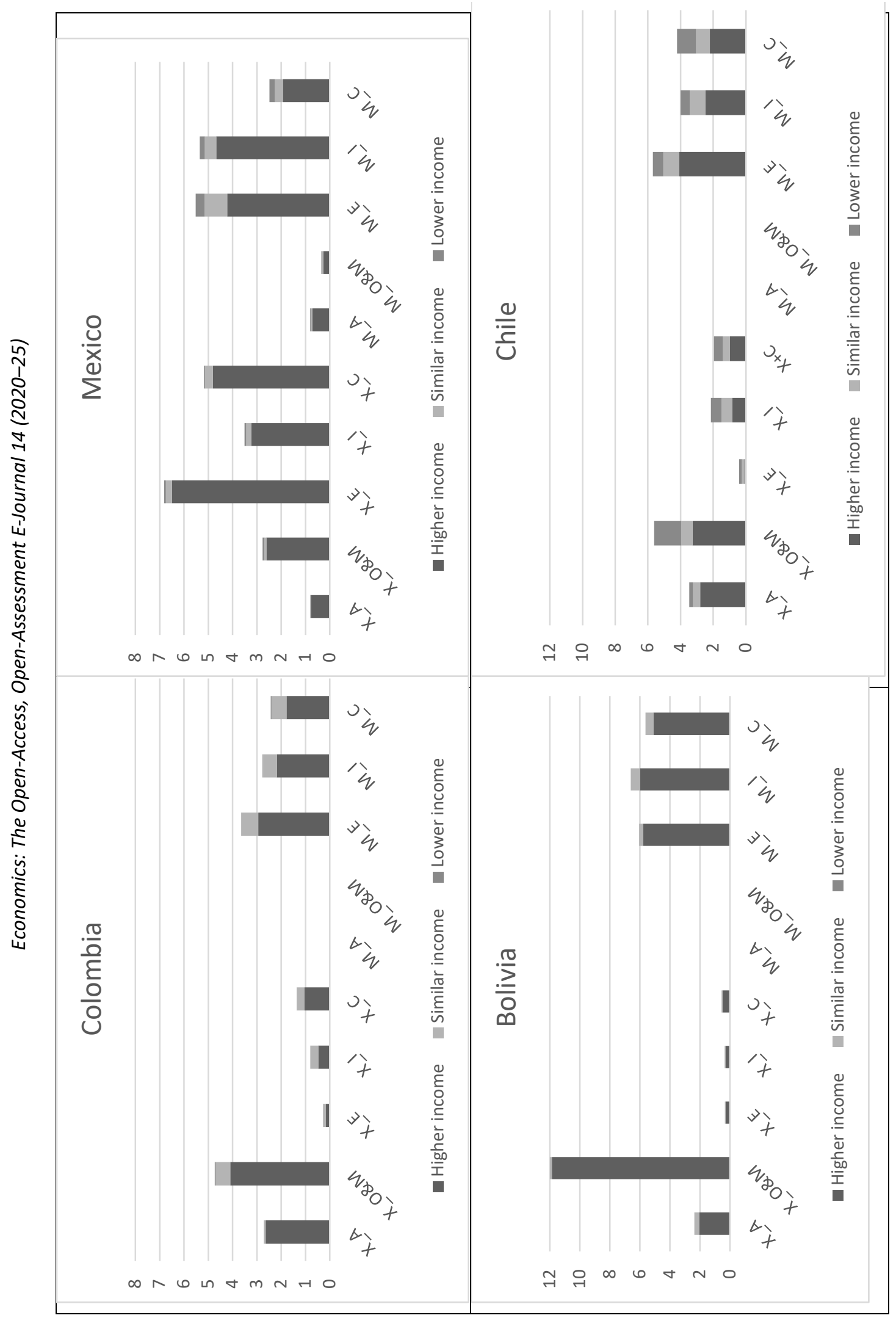




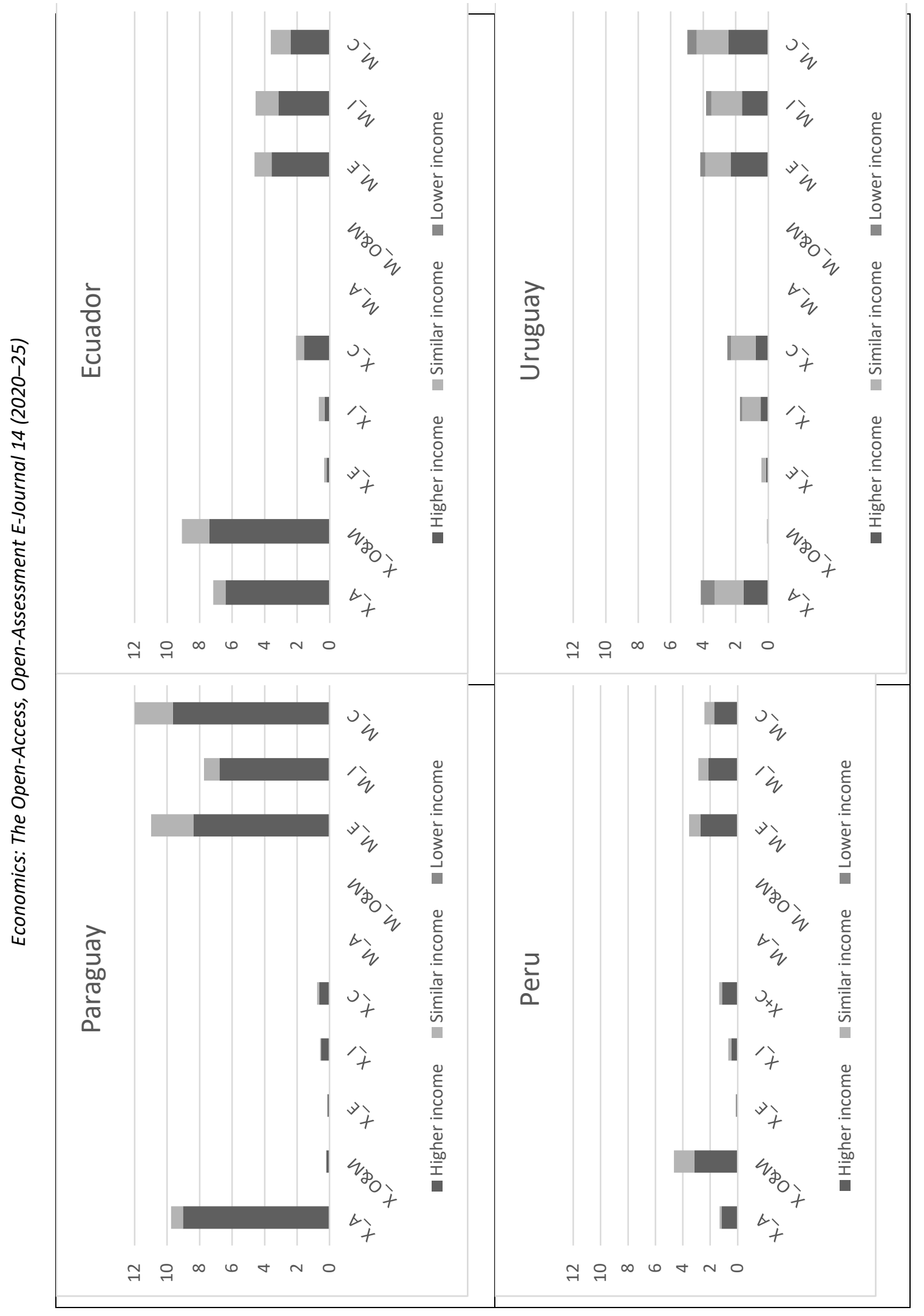




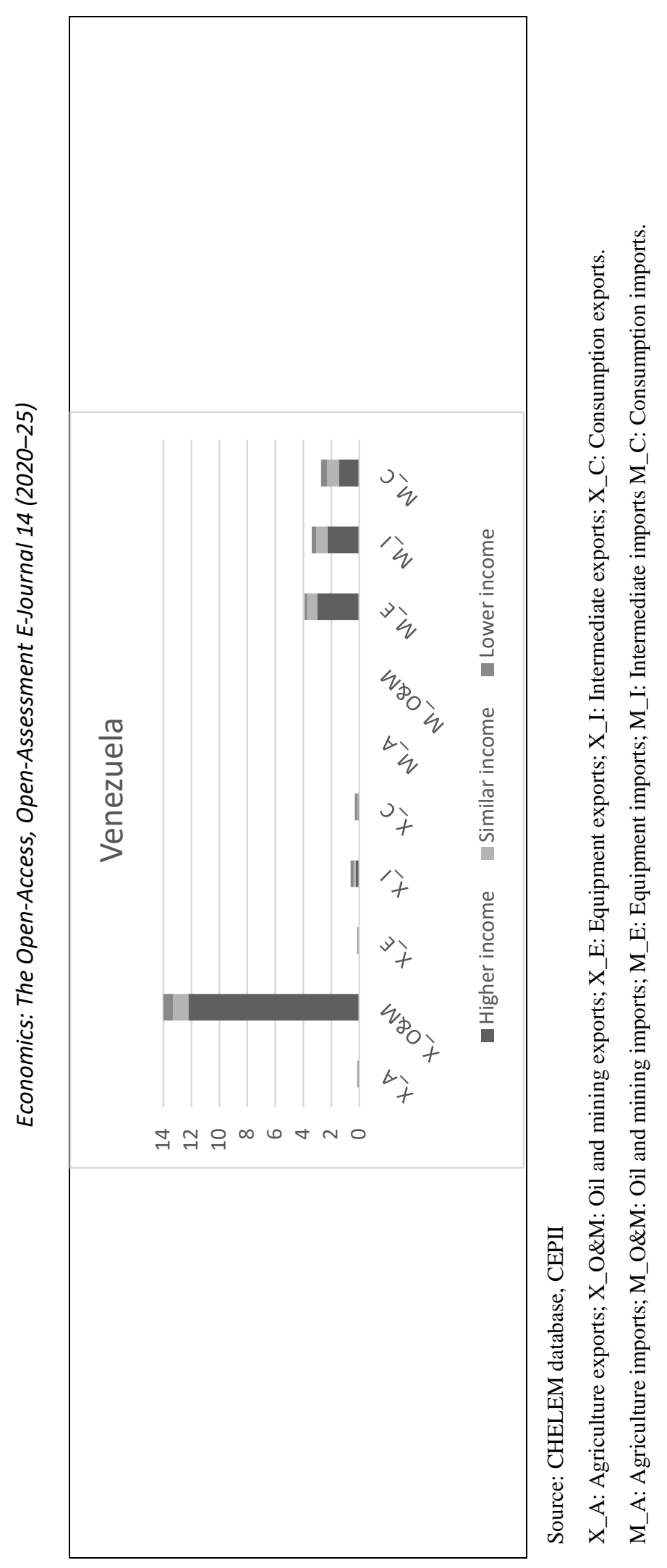




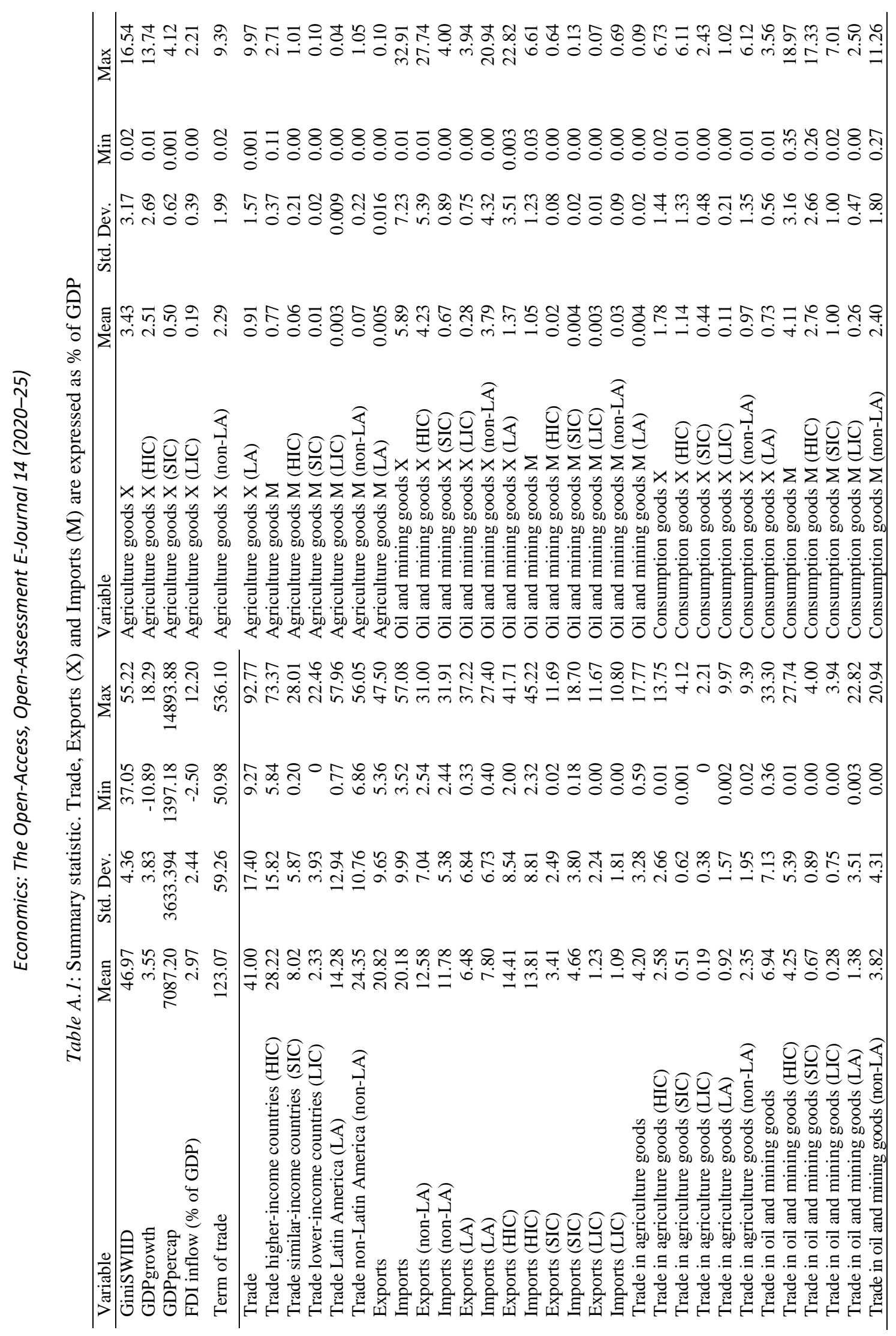




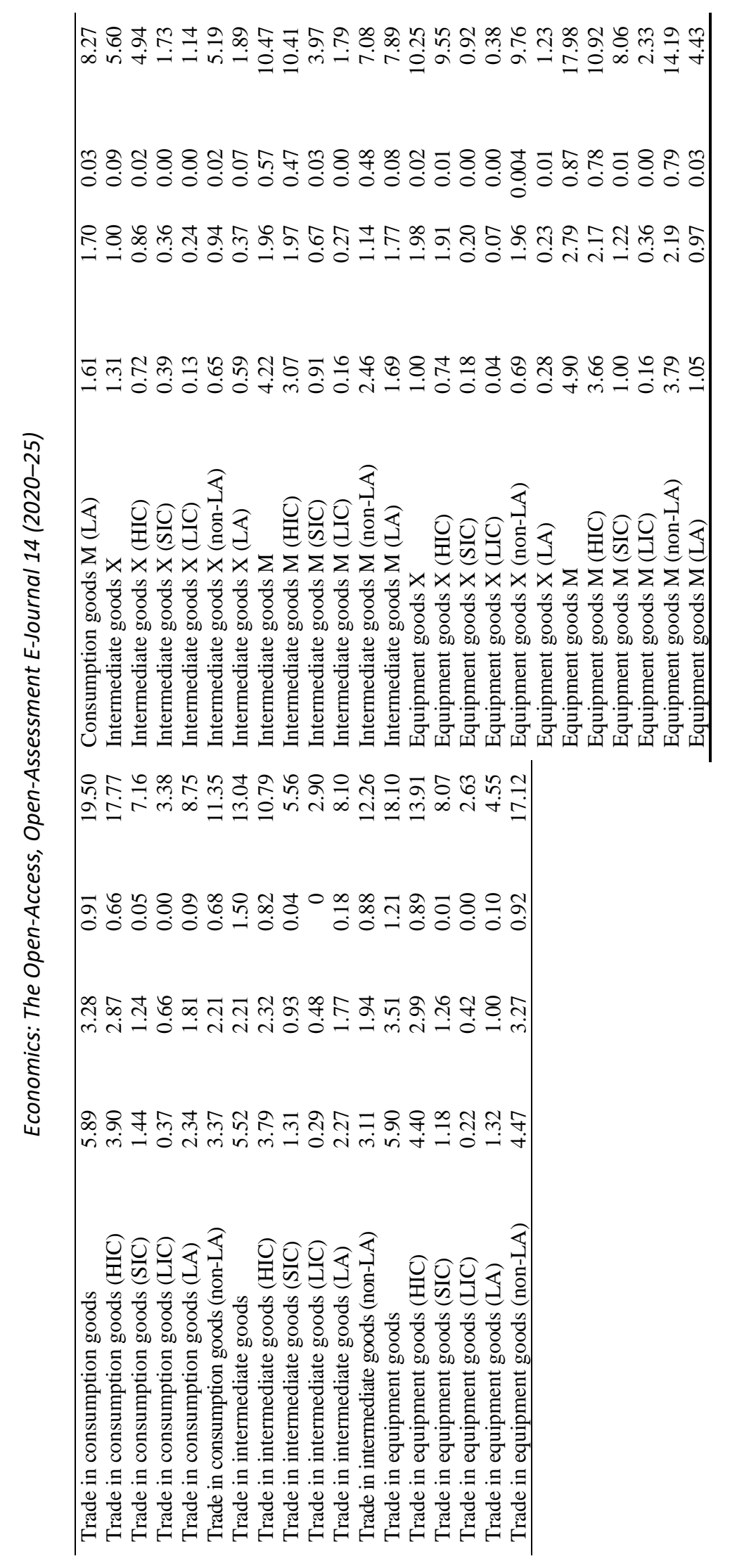




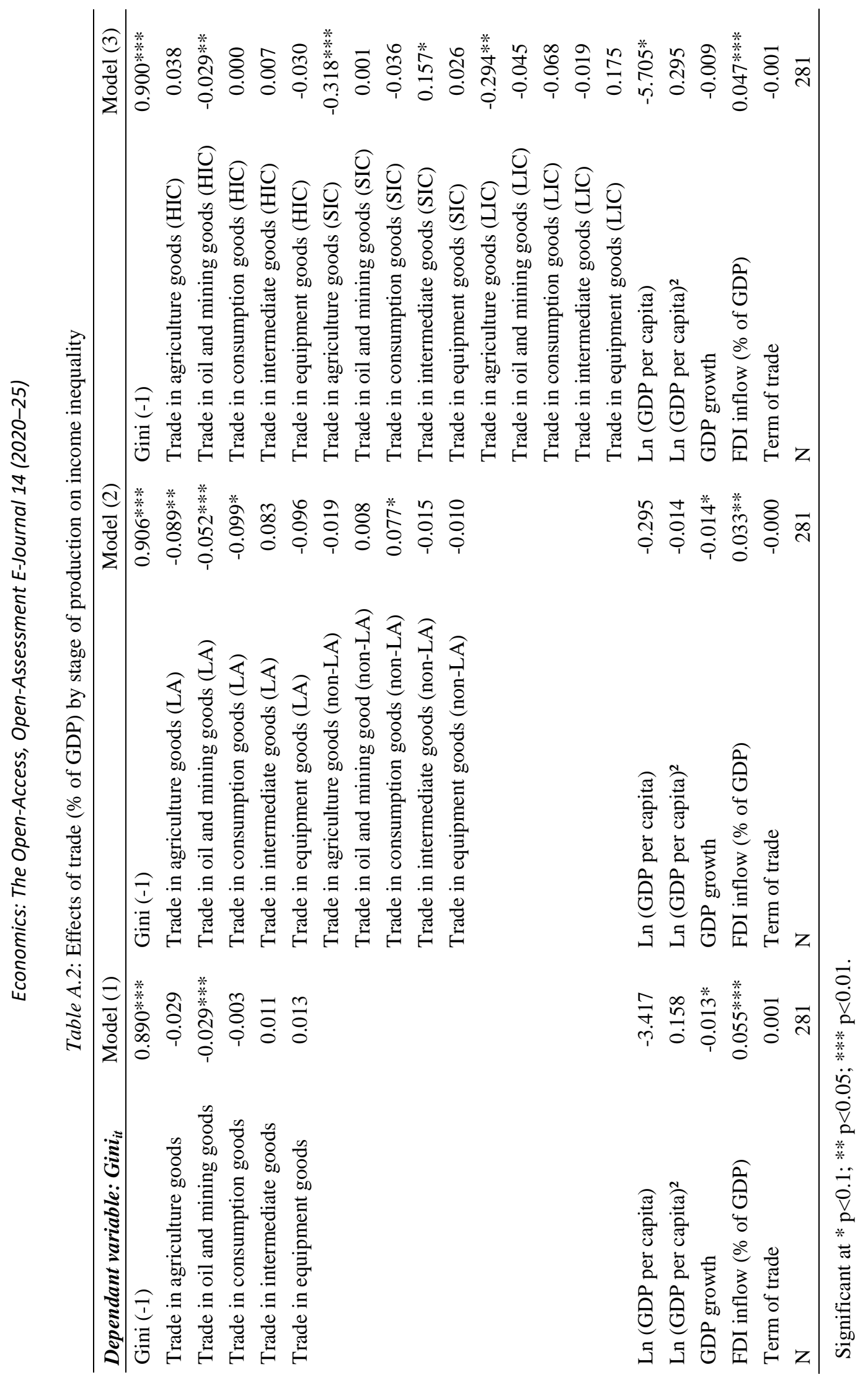




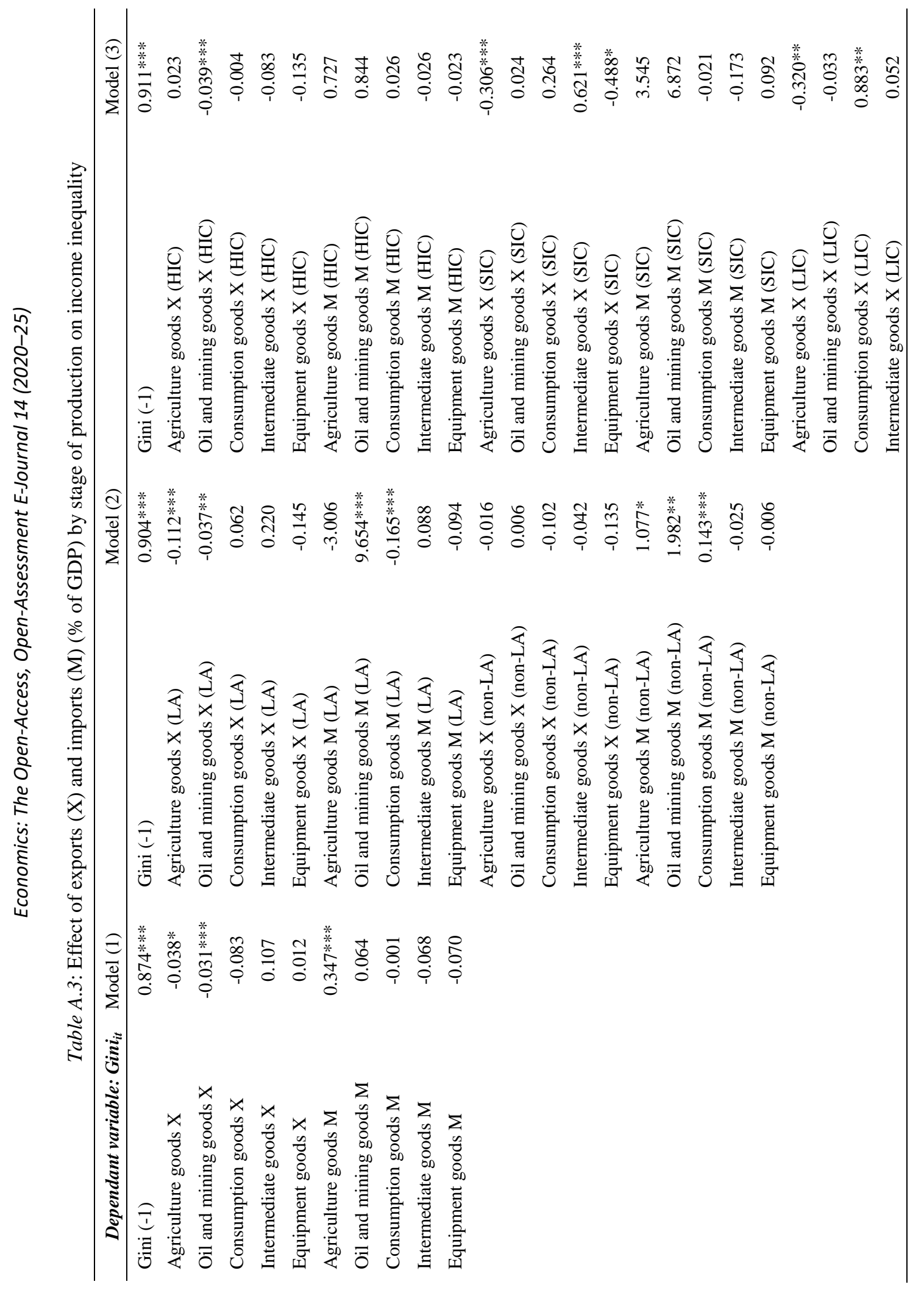




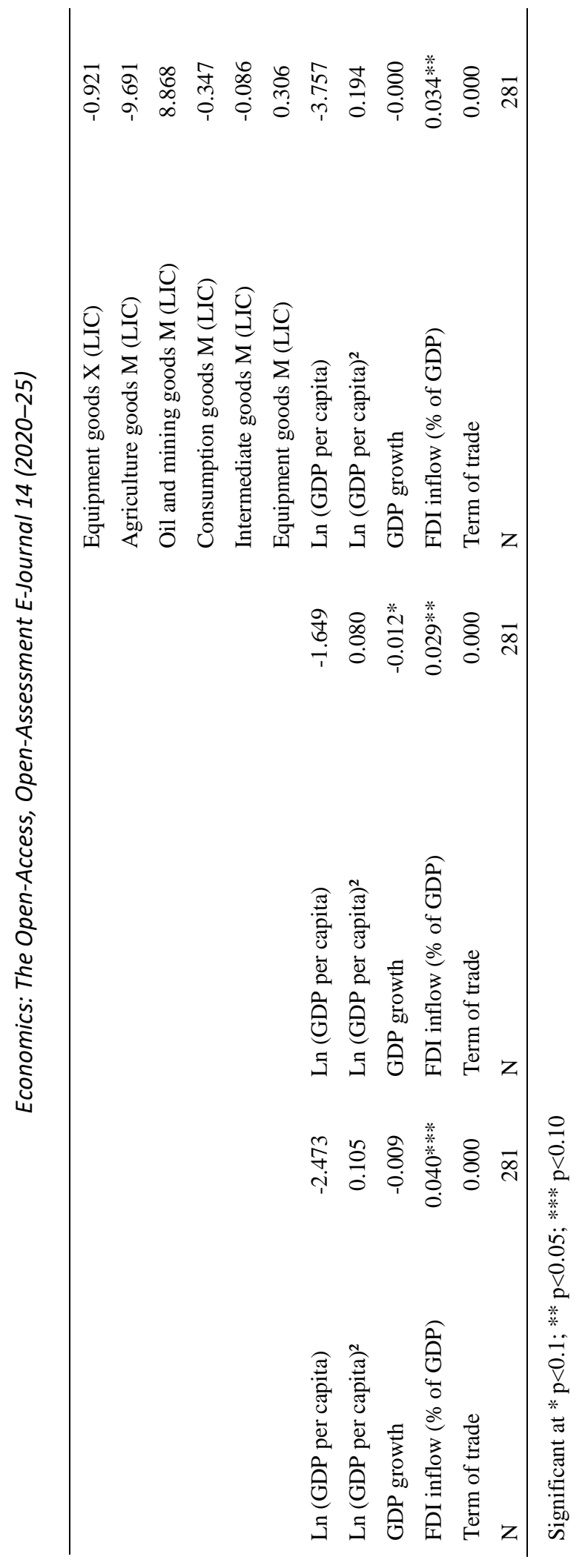

